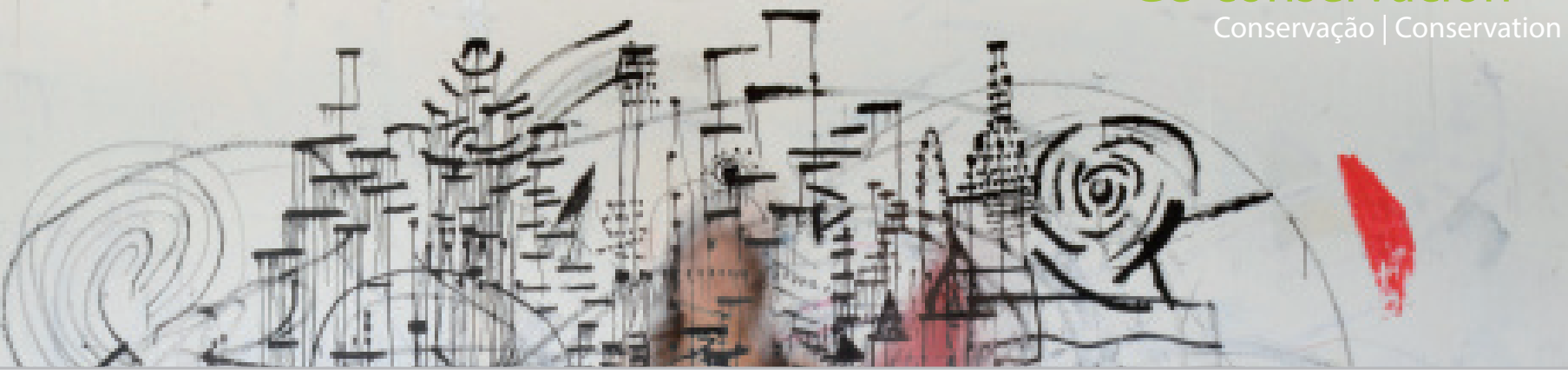

\title{
Más Allá del Museo: El Conservador de Arte Contemporáneo en el Sector Privado. Desafíos, Procedimientos y Soluciones
}

\author{
Rita L. Amor García
}

Resumen: Desde una base puramente academicista, la conservación se encarga del mantenimiento de objetos artísticos e históricos para el disfrute de generaciones presentes y futuras. De forma implícita, esto se relaciona comúnmente con museos e instituciones culturales públicas, así como con el trabajo de conservación que se realiza en tales espacios. No obstante, la conservación no solo trabaja en sectores públicos, ya que el sector privado es una fuente considerable de trabajo para muchos conservadores que emplean sus conocimientos y experiencia en situaciones algo más particulares. A las problemáticas en la conservación del arte contemporáneo respecto a nuevas técnicas, conceptos y materiales, se le añaden eventualidades (daños diversos) que podrían haber sido fácilmente evitados si ciertas pautas hubieran sido marcadas de antemano. De esta manera, el siguiente artículo expone cómo el coleccionismo de arte contemporáneo y la conservación se relacionan actualmente con el objetivo de presentar situaciones experimentadas y plantear soluciones concretas fácilmente aplicables.

Palabras clave: Coleccionismo, conservación, sector privado, casas de subastas, toma de decisiones, conservación preventiva, arte contemporáneo, soluciones

\section{Beyond the Museum: The Conservator of Contemporary Art in the Private Sector. Challenges, Procedures and Solutions}

Abstract: On a purely academic basis, conservation focuses on the maintenance of artistic and historical objects for the enjoyment of present and future generations. Implicitly, this is commonly related to museums and public cultural institutions, as well as the conservation work that takes place in such places. However, conservation does not only work in public sectors, as the private sector is a considerable source of work for many conservators who employ their knowledge and experience in often demanding situations. In addition to the problems of contemporary art with regards to new techniques, concepts and materials, there are eventualities and damages that could have easily been avoided if certain guidelines had been set beforehand. The following article presents how contemporary art collecting and conservation are related with the aim of introducing situations experienced by conservators and proposing concrete solutions that can be easily applied.

Keywords: Collecting, conservation, private sector, auction houses, decision-making, preventive conservation, contemporary art, solutions

\section{Coleccionismo y museos}

Desde la Antigüedad, el ser humano ha compartido la idea de preservar, admirar y guardar piezas únicas de valor estético, histórico, sentimental, etc. Esa idea de acumular objetos y obras, o coleccionismo, creció de civilización a civilización ${ }^{[1]}$, facilitando la preservación de obras del pasado, así como de objetos insólitos.

A través de las distintas épocas, el coleccionismo muestra similitudes en las intenciones de los coleccionistas, el

\section{Collecting and museums}

Since ancient times, humans have shared the idea of preserving, admiring and storing unique pieces of aesthetic, historical, or sentimental value. This idea of accumulating objects and works, or collecting, grew from civilisation to civilisation ${ }^{[1]}$, facilitating the preservation of both works from the past and unusual objects.

Throughout the ages, collecting depends on the intentions of collectors, the transfer of knowledge, and 
traspaso de conocimiento, y también en el modo de coleccionar, aunque este evoluciona dependiendo de la cantidad, forma y procedencia de las piezas que se adquieren. Desde la Era de los Descubrimientos (siglos XV a XVIII), la recopilación de objetos exóticos de América y Asia, así como de muestras naturalistas, fueron de gran importancia para la medicina, la botánica, la zoología y la alimentación, todo ello mostró la variedad de objetos que podían ser coleccionados, como fue la colección de Sir Hans Sloane (Delbourgo 2017). Estos objetos recolectados eran expuestos dentro de los "gabinetes de curiosidades" accesibles al público para su disfrute y estudio (Pardo-Tomás 2018). Un ejemplo en España sería el Gabinete de Historia Natural, primer museo público abierto en España (siglo XVIII) surgido de las expediciones de Carlos III (Bolaños 2008: 129-131). En Reino Unido, la colección de Sir Hans Sloane se puede todavía encontrar en Londres, en el Museo Británico [Figura 1] y el Museo de Historia Natural.

Respecto a la evolución y variedad, el coleccionismo no se mostraba únicamente con la idea de poseer, observar o dar a conocer objetos de estudio en las diferentes ramas de la ciencia, sino que el valor estético, el valor artístico, el valor histórico e incluso el valor sentimental también also the manner of collecting - although this evolves depending on the quantity, form and provenance of the pieces being acquired. From the Age of Discovery (15th to 18th centuries), the collection of exotic objects from America and Asia, as well as naturalistic specimens, grew of great importance for medicine, botany, zoology and food, all of which showed the variety of objects that could be collected, as can be seen, for example, in the collection of Sir Hans Sloane (Delbourgo 2017). These collected objects were exhibited within the "cabinets of curiosities" accessible to the public for their enjoyment and study (Pardo-Tomás, 2018). An example in Spain would be the Gabinete de Historia Natural, the first public museum opened in Spain (18th century) arising from the expeditions of Charles III (Bolaños 2008: 129131). In the United Kingdom, Sir Hans Slone's collection is still displayed at the British Museum [Figure 1] and the National History Museum.

In terms of evolution and variety, collecting was not just about owning, observing or making known objects for study in the different branches of science, but aesthetic, artistic, historical, and even sentimental value were also latent, and are still present in this

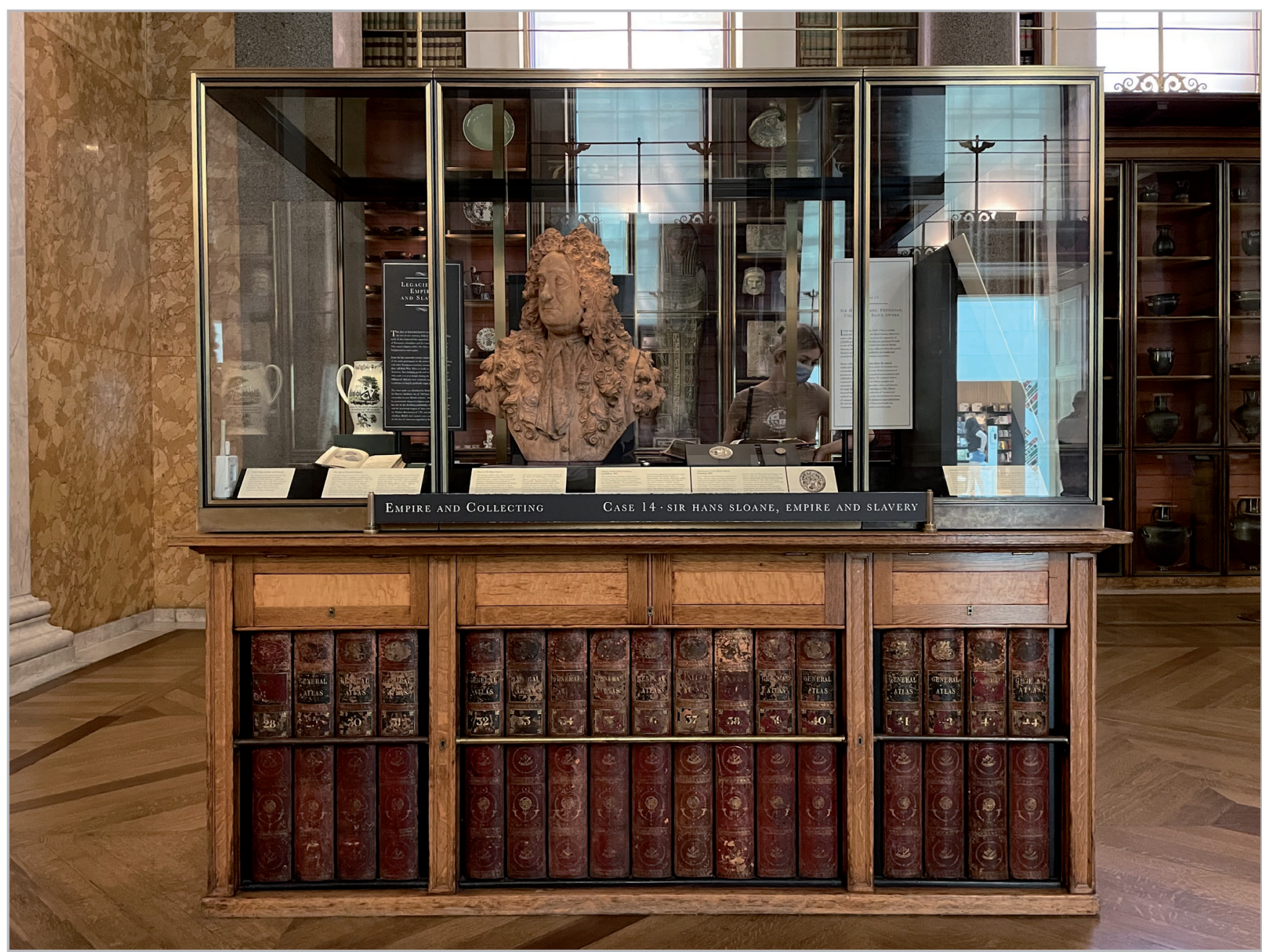

Figura/Figure 1- Sección sobre la colección de Sir Hans Sloane en el British Museum, Londres. / Section on Sir Hans Sloane's collection at the British Museum, London 
estaban latentes, y siguen presentes en ese sentido. Las grandes colecciones reales de pintura y escultura en Europa o colecciones privadas como la de Leopoldo de Medici (Dall'Aglio 2020) son algunos ejemplos en los que las piezas son apreciadas por su belleza y lo que relatan, por encima de otros aspectos de estudio que posean.

Lo cierto es que muchos de los grandes museos y colecciones públicas de historia y arte que se conocen hoy en día surgieron de la práctica del coleccionismo privado (Ntoulia 2017; García Felguera et al. 2018). Esta práctica es aún común en el siglo XIX, la cual se ve reflejada en museos que aumentan su colección notablemente a través de diferentes mecanismos: desde donaciones y legados, depósitos, hasta préstamos indefinidos y temporales, pasando por la posibilidad de adquirir colecciones completas de la mano de coleccionistas particulares.

No obstante, el coleccionismo privado no siempre se relaciona con la idea de ceder, vender o donar la colección a una institución pública, sino que su intención primaria suele ser la de adquirir piezas u obras de valor relevante o especial para un público general o particular, para el uso y disfrute personal. Desde mantener piezas heredadas, a adquirir nuevas, el coleccionismo siempre ha dependido del gusto, la percepción o los planes en cada caso, el cual puede relacionarse a un interés racional o irracional en conseguir ese objeto u objetos deseados. De esta manera, el coleccionista se siente autorrealizado por la posesión y admiración del objeto dentro de un espacio propio (Mclntosh y Schmeichel 2004: 87).

\section{Coleccionismo de arte contemporáneo}

Hoyen día, el coleccionismocontinúa nosolosiendouna práctica extendida, sino que la actividad misma cumple notablemente con las necesidades de la sociedad contemporánea, esto lo ha convertido en un mercado ampliamente especializado y funcional en el ámbito del arte y los objetos históricos. La figura del coleccionista continúa en individuos que agrupan obras de un artista o periodo determinado, pero también se ha visto ampliada a individuos que desean poseer una obra de gran valor artístico y alto valor económico como una inversión a futuro, lo cual se ve notablemente fomentado por las agencias especialistas en el mercado del arte (casas de subasta, galerías, marchantes, etc). Como expone Neil Brodie:

The actors and agencies of the art world act culturally to create and sustain consensual belief in the symbolic (including aesthetic) qualities and values (including monetary) of cultural objects, and socially and materially to construct and maintain the market for their exchange. (2019:2)

En esencia, la idea de coleccionismo de obras de arte de épocas pasadas y presentes viene identificada como una práctica de desembolso para unos pocos, en las que obras únicas van a parar a espacios concretos y exclusivos, más sense. The great royal collections of painting and sculpture in Europe or private collections such as that of Leopold de Medici (Dall'Aglio 2020) are examples in which the pieces are appreciated for their beauty and what they tell, above other aspects of study that they might possess.

The truth is that many of the great museums and public collections of history and art that are known today emerged from the practice of private collecting (Ntoulia 2017; García Felguera et al. 2018). This practice is still common in the nineteenth century, which is reflected in museums increasing their collection significantly through different mechanisms: from donations and bequests, deposits, to indefinite and temporary loans, together with the possibility of acquiring complete collections from private collectors.

However, private collecting is not always related to the idea of loaning, selling or donating the collection to a public institution. Actually, its primary intention is usually to acquire pieces or works of relevant or special value for a general or private public, for personal use and enjoyment. From keeping inherited pieces to acquiring new ones, collecting has always depended on taste, perception or plans in each case. This can be related to a rational or irrational interest in obtaining the desired object or objects. In this way, the collector feels self-realised by the possession and admiration of the object within a space of his or her own (Mclntosh and Schmeichel 2004: 87).

\section{Collecting contemporary art}

Today, collecting continues not only to be a widespread practice, but an activity that aligns with the needs of contemporary society to a remarkable degree, which has made it a highly specialised and functional market in the field of art and historical objects. The figure of the collector continues in individuals who gather together works by a particular artist or period, but it has also been extended to individuals who wish to own a work of great artistic value and high economic value as a future investment. This is notably encouraged by agencies specialising in the art market (auction houses, galleries, dealers, etc.). As Neil Brodie puts it:

The actors and agencies of the art world act culturally to create and sustain consensual belief in the symbolic (including aesthetic) qualities and values (including monetary) of cultural objects, and socially and materially to construct and maintain the market for their exchange. (2019:2)

In essence, the idea of collecting works of art from past and present times is identified as a practice of disbursement for the few, in which unique works end up in specific and exclusive spaces, beyond public collections 
allá de colecciones de carácter público como museos o instituciones gubernamentales. Pero como cualquier práctica, el coleccionismo de arte presenta diferentes públicos y niveles de accesibilidad. Además, el mercado del arte contemporáneo abre otras posibilidades en estos aspectos. La contemporaneidad de la obra con el artista ofrece la posibilidad de adquirir obras directamente de los artistas o sus galerías representantes (mercado primario), además de otros entornos más tradicionales, donde las obras ya han sido compradas con anterioridad, como las casas de subasta (mercado secundario), o incluso en ferias de arte. En todos los casos, la posibilidad de adquisición variará dependiendo de la importancia dada y con ello, la cotización de la obra del artista, teniendo en cuenta que la obra de un artista será más accesible cuando este esté todavía vivo (Lindemann 2006:11-12).

Naturalmente, las siempre presentes autenticidad y limitación de las obras hacen que el acceso a coleccionar grandes obras de arte $u$ objetos de patrimonio se vea alterado por el factor económico, que se aplica a su vez por esa esencia de la pieza única, y con ello esté circunscrito a aquellos más pudientes. Pero, en realidad, la exclusividad de adquisición de obras de arte no siempre implica una estricta incapacidad de deleite de obras particulares en favor de los ojos de unos pocos, ya que la compra-venta de arte abre también la posibilidad de apreciar piezas particulares en entornos no museísticos pero aun así accesibles a todos (si se conoce de su existencia). Estas serían las exposiciones en galerías especializadas [Figura 2], las exposiciones preventa de las casas de subasta [Figura 3], y por supuesto, las exposiciones temáticas temporales en museos y otras instituciones, las cuales en su gran mayoría exhiben obras cedidas temporalmente por otros museos, así como por coleccionistas privados [Figura 4]. such as museums or government institutions. But like any practice, art collecting has different audiences and levels of accessibility. Moreover, the contemporary art market opens up other possibilities in this respect. The contemporaneity of the work with the artist offers the possibility of acquiring works directly from them or their representative galleries (primary market), in addition to other more traditional environments, where the works have already been bought previously, such as auction houses (secondary market), or even at art fairs. In all cases, the possibility of acquisition will vary depending on the given importance and thus the value of the artist's work, bearing in mind that an artist's work will be more accessible when they are still alive (Lindemann 2006:1112).

Naturally, the ever-present authenticity and limitation of works means that access to collecting great works of art or heritage objects is altered by the economic factor, which in turn is applied by that essence of the unique piece, and is thus circumscribed to those who are wealthier. But, in reality, the exclusivity of acquiring works of art does not always imply a strict exclusivity of enjoyment of particular works for the eyes of a few, since the buying and selling of art also opens up the possibility of appreciating particular pieces in some nonmuseum environments still accessible to everyone (or to those who know how to access to them). These would be the exhibitions in specialised galleries [Figure 2], the presale exhibitions of auction houses [Figure 3], and of course, the temporary thematic exhibitions in museums and other institutions, most of which exhibit works on temporary loan from other museums, as well as from private collectors [Figure 4].

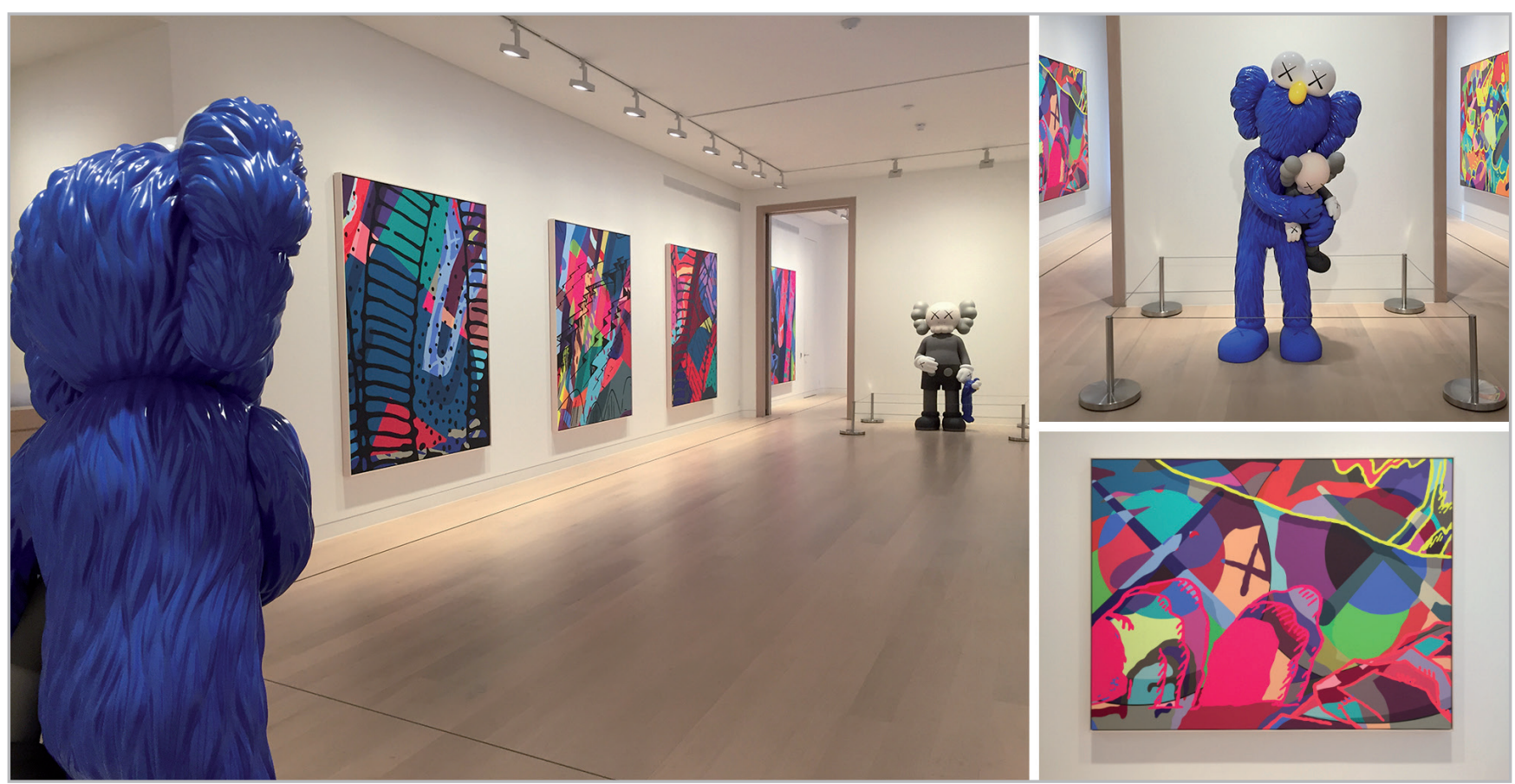

Figura/Figure 2- Exposición 'Kaws: Blackout' en la galería Skarstedt, Londres, octubre - noviembre 2019. / Kaws' exhibition 'Blackout' at Skarstedt Gallery, London, 2019. 

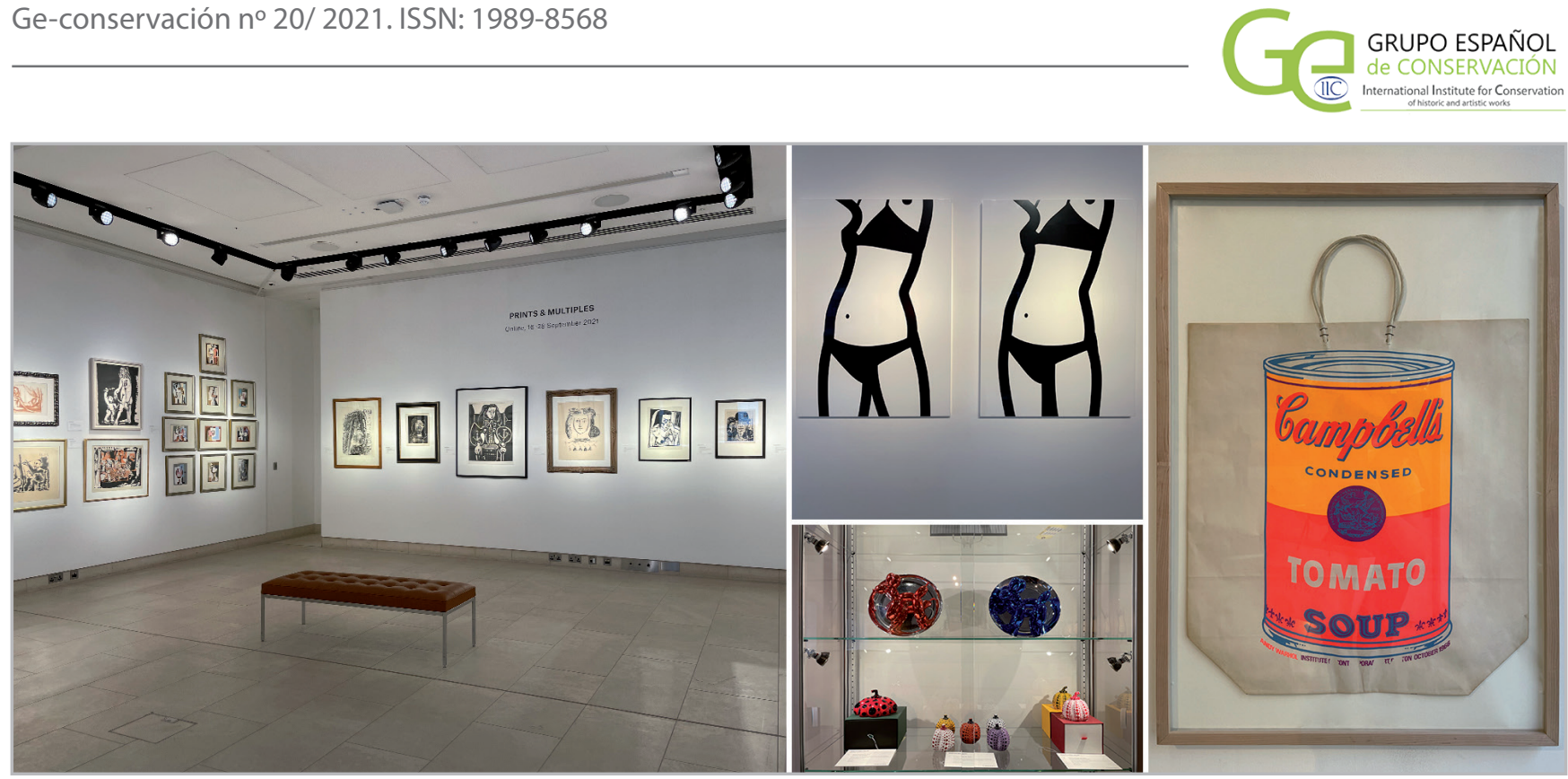

Figura/Figure 3- Exposición pre-subasta "Prints and Multiples" en Christie's, Londres, septiembre 2021. / Pre-auction exhibition "Prints and Multiples" at Christie's London, September 2019.
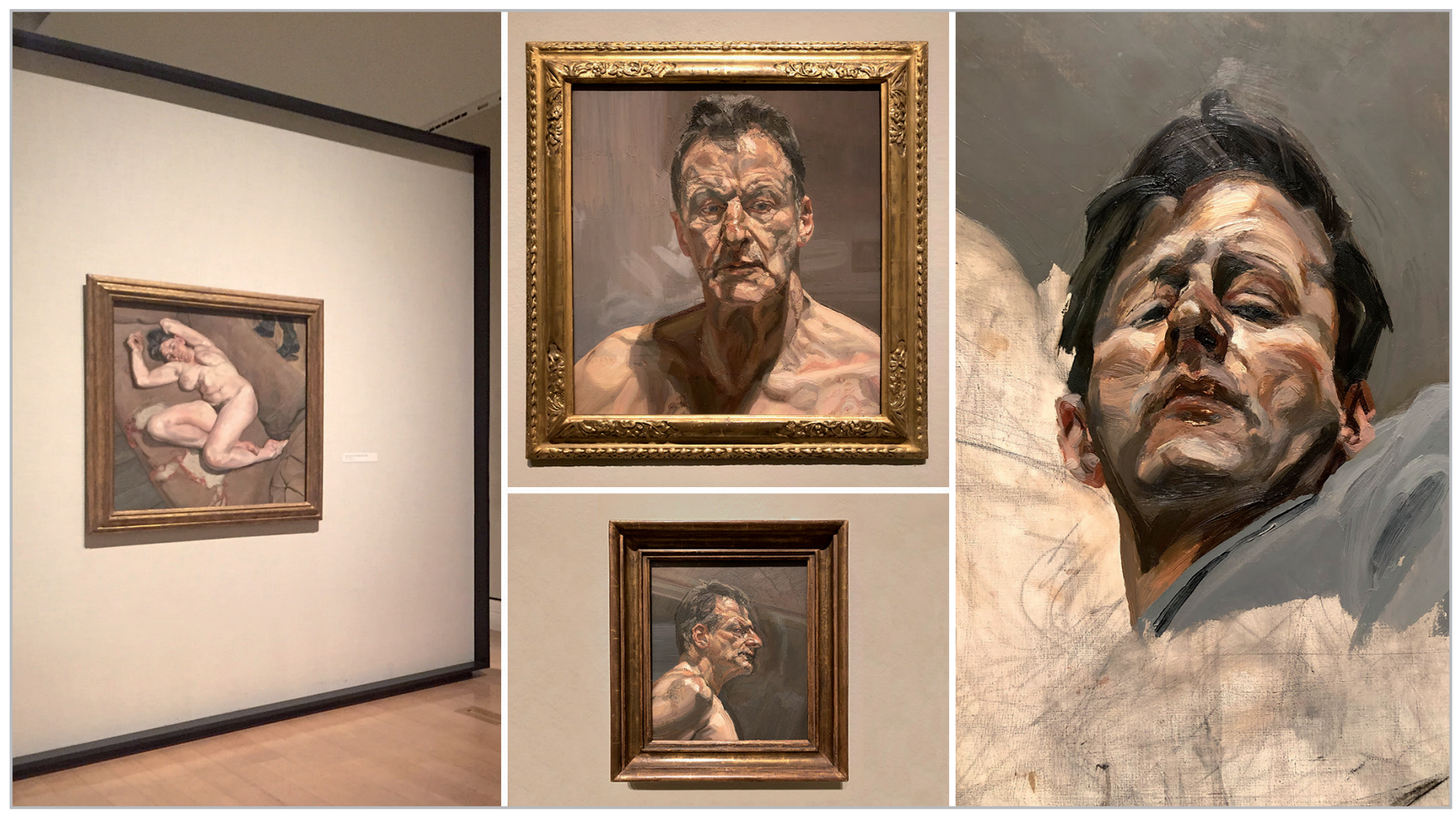

Figura/Figure 4- Exposición 'Lucian Freud: The Self-portraits'en la Royal Academy of Arts, Londres, octubre 2019- enero 2020. / Lucian Freud: The Selfportraits' exhibition at the Royal Academy of Arts, London, October 2019 - January 2020.

Pero hay que tener en cuenta que sea cual sea el entorno de exposición, las necesidades de cuidado y mantenimiento de obras pertenecientes a colecciones privadas requieren los mismos mecanismos de conservación ${ }^{[2]}$ que las obras en colecciones en entorno público. Este artículo se centra en las actividades de conservación aplicadas a grandes y pequeñas colecciones de arte contemporáneo, centrándose en el sector privado.

\section{Conservación en el sector privado}

Los parámetros físicos de la conservación en el sector privado no
But it should be borne in mind that whatever the exhibition environment, the care and maintenance needs of works belonging to private collections require the same conservation mechanisms as works in a public environment ${ }^{[2]}$. This article focuses on conservation activities applied to large and small contemporary art collections, with a focus on the private sector.

\section{Conservation in the private sector}

The physical parameters of conservation in the private 
se centran únicamente en colecciones sino también en el estudio y tratamiento de obras individuales en cualquier espacio (durante almacenaje, transporte, preparación o exposición) y bajo cualquier circunstancia. Estas tareas, por lo común, son desarrolladas por conservadores que trabajan en estudios privados o de manera autónoma, los cuales pueden además realizar trabajos para instituciones públicas, dependiendo de su especialidad, rango de trabajo o las necesidades de los museos y obras.

Es común que los conservadores de arte contemporáneo posean una serie de habilidades extendidas que no se centren en un campo de especialidad único, así como una relevante adaptabilidad a las circunstancias del espacio, de las obras y de las necesidades de los clientes (privados y públicos). Con ello, el trabajo de conservador de arte contemporáneo se clasifica como especializado y a la vez multifacético, ya que las obras en muchas ocasiones van más allá de un tipo de superficie tradicional (caballete, mural, escultura, etc.), lo cual obliga al especialista a centrarse en la variedad $u$ homogeneidad de los materiales que componen la obra y en el empleo de las mejores soluciones en cada caso. Esto hace que el conservador de arte contemporáneo deba conocer y pueda aplicar tratamientos variados en diferentes superficies y estratos, estudie e investigue sobre nuevos tratamientos y posibilidades de forma continuada y considere, recomiende y aplique acciones de prevención por encima de tratamientos más directos. Este último punto, es especialmente vital en la conservación de obras de arte contemporáneo, ya que la fragilidad y complejidad de los materiales empleados hace que las acciones preventivas sean prioritarias en cualquier caso.

Así, en términos de preservación y degradación, las obras de arte contemporáneo vinculadas al sector privado se muestran sujetas a un incremento de factores de riesgo directos e indirectos, los cuales se podrían vincular a tres aspectos generales: la localización y el entorno, los protocolos de conservación, y el desconocimiento de las necesidades de la obra [Figura 5].

En primer lugar, los espacios donde se exponen las obras son diversos, a veces variables debido a traslados frecuentes, y además las condiciones de los espacios (vigilancia, control ambiental, etc) son excepcionales en comparación con las ofrecidas en espacios museísticos. La diversidad de los espacios es tan amplia que es imposible determinar unas condiciones del entorno concretas donde estas obras se suelen encontrar, ya que estas varían dependiendo de si la obra se expone en una vivienda, una oficina, una galería, etc. Con ello, la habitabilidad (permanente, temporal o rara), su distribución, funcionalidad, uso y condiciones ambientales serán aspectos que podrán interferir directa o indirectamente en el estado de conservación de una obra o colección.

En segundolugar, son muchos los casos en los que los protocolos generales que los especialistas de conservación sugieren para mantener las obras de arte contemporáneo en su mejor estado, no son aplicados, y en muchos casos desconocidos, ya que las obras no han sido evaluadas por conservadores anteriormente. Este es un problema común y lamentablemente la causa sector do not only focus on collections but also on the study and treatment of individual works in any space (during storage, transport, preparation or exhibition) and under any circumstances. These tasks are usually carried out by conservators working in private studios or on a freelance basis, who may also carry out work for public institutions, depending on their speciality, scope of work and the needs of the museums and artworks.

It is common for contemporary art conservators to possess a wide range of skills that do not focus on a single field of expertise, as well as a relevant adaptability to both the circumstances of the space, and the needs of the art works and the clients (private and public). The contemporary art conservator's role is thus classified as specialised and multifaceted, as the works often go beyond a traditional type of surface (easel, mural, sculpture, etc.), which forces the specialist to focus on the variety or homogeneity of the materials used in the artwork, and on the application of the best solutions in each case. This means that the contemporary art conservator must know and be able to apply varied treatments to different surfaces and layers, study and research new treatments and possibilities on an ongoing basis, and consider, recommend and apply preventive actions rather than more direct treatments. This last point is especially vital in the conservation of contemporary artworks, as the fragility and complexity of the materials commonly used makes preventive actions a priority in any case.

Thus, in terms of preservation and degradation, contemporary artworks within the private sector are subject to an increase in direct and indirect risk factors, which can be linked to three general aspects: location and environment, conservation protocols, and lack of knowledge of the artwork's needs [Figure 5].

Firstly, the spaces where the works are exhibited are diverse, sometimes variable due to frequent transfers, and also the conditions of the spaces (surveillance, environmental control, etc.) are exceptional compared to those offered in museum spaces. The diversity of spaces is so wide that it is impossible to determine specific conditions of the environment where these works are usually found, as these vary depending on whether the work is exhibited in a home, an office, a gallery, etc. Thus, the habitability (permanent, temporary or rare), space distribution, functionality, use and environmental conditions will be aspects that may directly or indirectly interfere with the state of conservation of an artwork or collection.

Secondly, there are many cases in which the general protocols suggested by conservation specialists to keep contemporary artworks in their best condition are not applied, and in many other cases, are unknown as the works have not been assessed by conservators before. This is a common problem and unfortunately the cause 
de muchos daños que podrían haber sido evitados en obras contemporáneas. Los protocolos evalúan los riesgos directos e indirectos de esas obras y exponen sugerencias de cómo proceder en situaciones comunes, como son la manipulación, el traslado y las condiciones de exposición de las obras.

En tercer lugar, las necesidades específicas de la gran mayoría de las obras de arte contemporáneo requieren un conocimiento extensivo, no solo de mecanismos de conservación preventiva, sino también de los propios materiales compositivos. En ocasiones, la falta de una evaluación previa por un especialista o simplementeno seguir las sugerencias del artista u otro conocedor de la obra, pueden ser desastrosos para la misma. Además, en el caso de las obras realizadas con materiales de producción industrial, no-convencionales, efímeros o combinando materiales incompatibles, puede dar como resultado una alteración acelerada de los materiales empleados incluso en condiciones ideales. Es por ello que, aparte de las problemáticas comunes, deben tomarse consideraciones extras en todos los casos, y ser conscientes de los riesgos y daños potenciales.

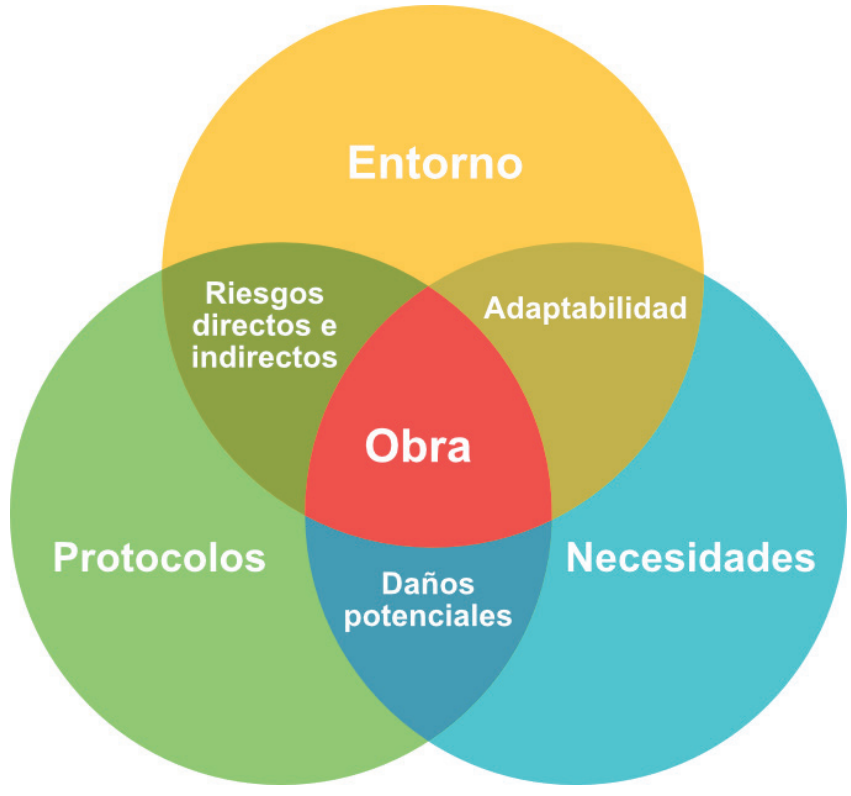

of many avoidable issues to contemporary artworks. The protocols assess the direct and indirect risks of such works and provide suggestions on how to proceed in common situations, such as handling, moving and exhibition requirements of the works.

Thirdly, the specific needs of the vast majority of contemporary works of art require extensive knowledge, not only of preventive conservation mechanisms, but also of the compositional materials themselves. Sometimes, the lack of a prior assessment by a specialist or simply not following the suggestions of the artist or another specialist can be disastrous for the work. Moreover, in the case of artworks made with industrial produced, nonconventional, ephemeral or combining incompatible components, can result in an accelerated alteration of the materials used even under ideal conditions. This is why, apart from the common issues, extra considerations must be taken into account in all cases, and awareness of potential risks and issues must be raised.

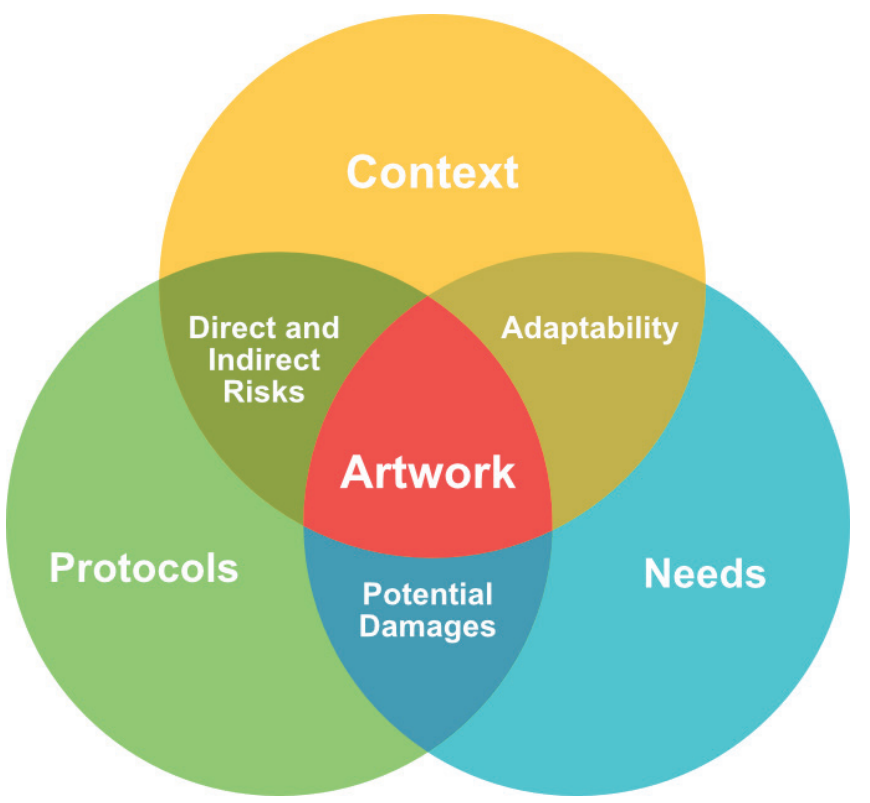

Figura/Figure 5- Diagrama Obra y Aspectos relativos a la Conservación. / Diagram of the Work and Conservation Aspects.

Como se mencionó anteriormente los materiales compositivos juegan un papel importante y paralelo a las acciones de conservación preventiva, ya que, otra serie de daños o alteraciones comunes en las obras de arte contemporáneo son los producidos por el envejecimiento natural y/o problemáticas de producción de los mismos. Es por ello que la aplicación de medidas preventivas es crucial, y es el conservador el responsable de aplicar los tratamientos de conservación necesarios para ralentizar estos procesos de degradación o envejecimiento siempre y cuando sea posible, y no interfieran con la intencionalidad del artista.

Estos tres aspectos generales están directamente relacionados con la conservación preventiva, ya que afecta a la adaptabilidad (o falta de ésta) de los espacios, las consideraciones a tener
As mentioned above, compositional materials play an important role in parallel with preventive conservation actions, since other common reasons of damages or alterations in contemporary artworks are those produced by natural ageing and/or production problems. This is why the application of preventive measures is crucial. Also, it is the conservator's responsibility to apply the necessary conservation treatments to slow down the degradation or ageing processes whenever possible, and only if they do not interfere with the artist's intention.

These three general aspects are directly related to preventive conservation, as they affect the adaptability (or lack thereof) of spaces, the considerations after the 
en cuenta tras la producción de la misma o cualquiera de los riesgos que pueden producir daños a corto, medio o largo plazo. Además, hay que destacar que estas alteraciones también pueden surgir momentos después de la producción de la obra si no existen (o no se aplican) unos protocolos de manipulación y mantenimiento concretos, por lo que existen casos donde los problemas aparecen antes de que la obra deje el estudio del artista, o en situaciones o espacios donde la obra se localiza antes, durante o después de su compra-venta.

En todo caso, la gran mayoría de las alteraciones producidas en las obras de arte contemporáneo pertenecientes a colecciones privadas se deben por un lado, a accidentes que podrían haber sido evitados con la correcta evaluación y manipulación, y por otro lado, a problemáticas relacionadas con la producción de la obra (materiales, técnicas, construcción). A esto se le suma que el mantenimiento de tales obras puede no ser tan regular como en colecciones de grandes instituciones o museos, requiriendo mecanismos de preservación, conservación y restauración en cualquier momento de la vida de la obra, pero especialmente en momentos delicados, muchas veces cuando el daño ya ha sido producido.

\section{Desafíos, consideraciones y soluciones}

En cuestiones de problemáticas experimentadas, sea por la producción, envejecimiento, manipulación o traslado de la obra, o simplemente por la localización de los espacios donde estas obras son expuestas o almacenadas, los factores de riesgo y degradación incrementan cuando las medidas aplicadas no son las correctas, o las particularidades de las obras no son tenidas en cuenta. Pero ¿cuáles son las situaciones que los conservadores de arte contemporáneo se encuentran cada día? Y ¿qué soluciones aplican a tales desafíos?

Desde participar en los preparativos previos y posteriores a exposiciones, hasta atender emergencias debidas a accidentes desafortunados, los conservadores que trabajan en el sector privado se enfrentan a situaciones variadas, extremas, desafiantes y desafortunadas, de las que intentan mantener un control de la situación intentando evaluar las posibilidades de los tratamientos con respecto a las mejoras potenciales en cada situación.

\section{- Toma de decisiones}

Tanto en situaciones donde un daño ha sido producido recientemente, como si este ha sido descubierto tras una larga temporada obviado o desconocido, el conservador inicia su participación en la resolución de un problema desde una posición de espectador. En esta, el especialista toma una postura que le permite establecer una visión global de la situación, recabar toda la información del punto del contacto con la obra y establecer la validez de la misma, ya que en muchas ocasiones algunos detalles pueden ser obviados, incorrectos o indirectamente confusos. Luego, estudiará la obra desde su composición a su construcción, production, or any of the risks that may cause damage in the short, medium or long terms. Moreover, it should be noted that these alterations can also arise moments after the production of the work if specific handling and maintenance protocols do not exist (or are not applied), so there are cases where the problems appear before the work leaves the artist's studio, or in situations or spaces where the artwork is located before, during or after its purchase and sale.

In any case, the vast majority of alterations produced in contemporary artworks belonging to private collections are due, on the one hand, to accidents that could have been avoided with the correct evaluation and handling, and, on the other hand, to problems related to the production of the work (materials, techniques, construction). In addition, the maintenance of such works may not be as regular as in the collections of large institutions or museums, requiring preservation, conservation and restoration mechanisms at any time in the life of the artwork, but especially at delicate moments, often when the damage has already occurred.

\section{Challenges, considerations and solutions}

In problematic situations, whether due to the production, ageing, handling or move of the artworks, or simply due to the location of the spaces where these are exhibited or stored, the risk and degradation factors increase when the measures applied are not the correct ones, or the particularities of the works are not taken into account. But what are the situations that contemporary art conservators encounter every day? And what solutions do they apply to these challenges?

From participating in pre- and post-exhibition preparations, to dealing with emergency calls due to unfortunate accidents, conservators working in the private sector are confronted with varied, extreme, challenging and unfortunate situations, of which they try to keep control of by trying to assess the prospective of treatments in relation to potential improvements in each individual case.

\section{- Decision-making}

Whether a situation where damage has only recently occurred, or when the damage has been discovered after a long period of being overlooked or unknown, the conservator begins their participation in the resolution of a problem from a position of spectator. In this position, the specialist takes a stance that allows them to establish an overall view of the situation, gather all the information from the client and establish the validity of the information provided by assessing the artwork, as in many cases some details may be overlooked, incorrectly disclosed or indirectly confusing. They will then study 
el estado actual de conservación y los daños directos e indirectos ${ }^{[3]}$. También será necesario establecer una comunicación fluida con el cliente en la que se puedan determinar las necesidades o requerimientos del mismo y exponer la viabilidad en la aplicación de tratamientos de conservación seguros para la obra basados en los criterios de conservación éticos. Este también será un buen momento para comunicar posibles mejoras en la exposición o almacenaje de la obra relativas a cómo hubiera podido evitarse el daño (por ejemplo, enmarcar obras que han sido directamente dañadas en la superficie).

Tras recoger toda la información necesaria sobre la obra, el entorno y el cliente, se podrá realizar la propuesta de intervención en la que se determinará la tipología o tipologías de tratamientos necesarios (estéticos y/o estructurales, generales o puntuales) y una estimación del nivel de mejora que se espera de los tratamientos dependiendo de las alteraciones mostradas. Si la propuesta establece la viabilidad de la intervención, esta continuará con pruebas que confirmen o nieguen la efectividad de la intervención, the work from its composition to its construction, the current state of conservation and direct and indirect damages ${ }^{[3]}$. It will also be necessary to establish a fluid communication with the client in order to identify their needs or requirements and the feasibility of supporting them in respect to safe conservation treatments based on ethical conservation criteria. This will also be a good time to communicate possible improvements in the display or storage of the work in relation to how the damage could have been avoided (e.g. framing works that have been directly damaged on the surface).

After gathering all the necessary information about the work, the environment and the client, the treatment proposal will be made, determining the type of treatment required (aesthetic and/or structural, general or specific) and an expected outcome depending on the alterations shown. If the proposal establishes the feasibility of the treatments, it will continue with tests that confirm or deny the effectiveness of the intervention, which will allow to proceed or cancel

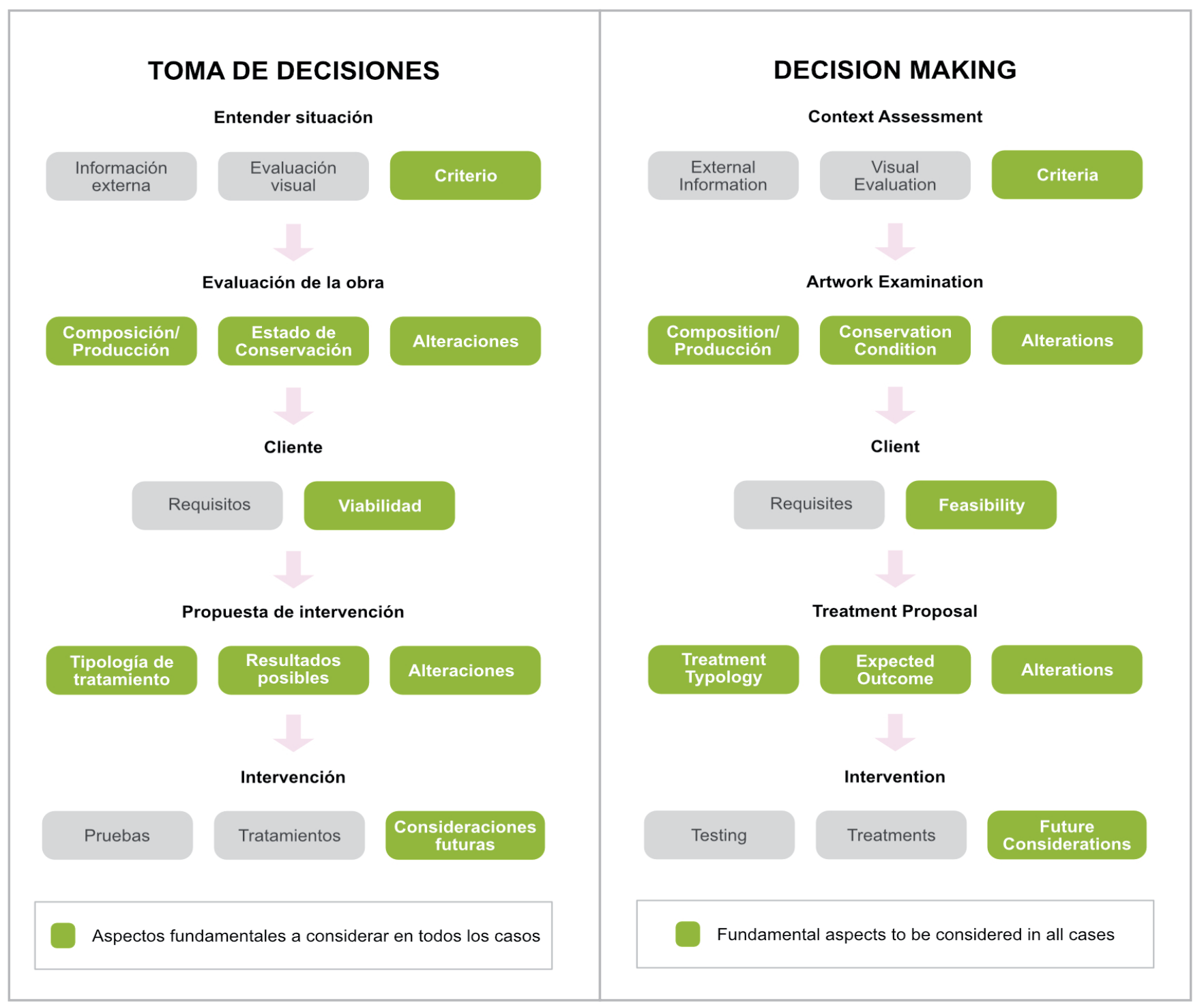

Figura/Figure 6-Diagrama simplificado sobre la Toma de Decisiones. / Simplified Decision-Making Diagram. 
y procederá o anulará los tratamientos de conservación planteados. Finalmente se podrán establecer consideraciones futuras (que se recomienda hacer por escrito) ampliando las recomendaciones que se hayan podido ofrecer durante la fase de diálogo con el cliente. Todos estos pasos forman parte del proceso de la toma de decisiones en situaciones donde se han producido alteraciones de las obras en colecciones privadas.

Para facilitar el estudio y comprensión de la conservación de la obra a aquellas personas interesadas en el proceso de la toma de decisiones o la conservación de la obra, es siempre recomendable que los datos recogidos sean compilados en un informe que deberá acompañar a la obra tras finalizar los tratamientos o la evaluación de la misma. De esta manera, no solo se informará de los daños que la obra haya podido experimentar anteriormente, sino también de otros factibles de ocurrir, así como subrayar aspectos a tener en cuenta sobre la composición y cuidado de la misma en el futuro a posibles coleccionistas.

El diagrama simplificado de la toma de decisiones expuesto [Figura 6] es una guía general basada en la experiencia de la autora en el campo de conservación en el sector privado, y adaptado según conveniente del modelo compilado por el SBMK en 1999 y actualizado en 2019 (Giebeler et al. 2019). Generalmente, estos modelos presentan similitudes en cuestiones de identificación y enfrentamiento a los problemas, pero el proceso de la toma de decisiones podrá variar dependiendo del especialista, las obras y las situaciones en las que estos se encuentren ${ }^{[4]}$.

\section{- Casos prácticos}

Con el objetivo de ofrecer no solo un servicio sino también las mejores soluciones en la preservación de todo tipo de colecciones, los conservadores trabajan junto a coleccionistas, galerías y centros expositivos privados, o en sectores todavía más comerciales, como las casas de subasta, ferias de arte y otros eventos relacionados. En todo caso, la postura del conservador respecto a los tratamientos o acciones a aplicar sobre estas obras se encuentra dentro de los mismos parámetros ofrecidos en museos y colecciones ${ }^{[5]}$, al mismo tiempo que se ofrece cierta adaptabilidad y, si es posible, flexibilidad dependiendo de las necesidades en cada caso. Esto está directamente relacionado con aquellas ocasiones donde los clientes (coleccionistas) expresan unos requisitos especiales para la conservación de la obra. En tales casos es la tarea del conservador el evaluar las posibilidades que los mecanismos de conservación disponibles pueden ofrecer de forma directa e indirecta a los desafíos que la obra y su entorno ofrecen. Esto incluirá desde proponer medidas preventivas o evitar que daños pasados no se vuelvan a repetir, a aplicar procedimientos específicos que ayuden al traslado y preparación de las obras, pasando por devolver la apariencia estética a una obra que ha sido dañada irreversiblemente, o realizar tratamientos "invisibles" para que las obras puedan ser restauradas a un estado inicial sin afectar el valor (económico) estimado de la obra. the conservation treatments proposed. Finally, future considerations might be established (likely in writing), expanding on the recommendations that may have been offered during the dialogue phase with the client. All these steps are part of the decision-making process in situations where alterations to artworks in private collections have occurred.

In order to facilitate the study and understanding of the conservation of the work for those interested in the decision-making process or the conservation of the artwork, it is always advisable that the data collected is compiled in a report accompanying the artwork after the end of the treatments or its evaluation. This will inform collectors of any potential damage that may occur, as well as highlighting aspects to be taken into account, in particular with regards to the composition and care of the artwork in the future.

The simplified decision-making diagram shown [Figure 6] is a general guide based on the author's experience in the field of conservation in the private sector, and adapted as appropriate from the model compiled by the SBMK in 1999 and updated in 2019 (Giebeler et al. 2019). Generally, these models have similarities in terms of identifying and facing issues, but the decision-making process may vary depending on the specialist, the artworks and the situations they are $\mathrm{in}^{[4]}$.

\section{- Issues and approaches}

In order to offer not only a service but also the best solution in the preservation of all kinds of collections, conservators work alongside collectors, galleries and private exhibition centres, or in even more commercial sectors, such as auction houses, art fairs and other related events. In all cases, the conservator's position regarding the treatments or actions to be applied to these works is within the same parameters offered to museums and collections ${ }^{[5]}$, while at the same time offering a certain adaptability and, if possible, flexibility depending on the needs of each case. This is directly related to those occasions where clients (collectors) express special requirements for the conservation of the work. In such cases it is the conservator's task to evaluate the possibilities that the available conservation mechanisms can offer directly and indirectly to the challenges that the work and its environment offer. This will range from proposing preventive measures or preventing past damage from recurring, applying specific procedures to assist in the removal and preparation of works, restoring the aesthetic appearance of a work that has been irreversibly damaged, to carrying out "invisible" treatments so that works can be restored to an initial state without affecting the estimated (economic) value of the work. 
comunes encontrados en los últimos cuatro años de experiencia de trabajo en el sector privado. Estos se dividen en alteraciones producidas en momentos de manipulación y traslado, exposición y montaje, almacenaje y tratamientos anteriores.

\section{- Manipulación y traslado}

A pesar de que uno de los principios básicos de cualquier especialista o conocedor de arte es que la manipulación de las obras debe realizarse empleando guantes (de algodón, látex, nitrilo), evitando el contacto directo de las manos con la superficie, encontrar huellas de manos y dedos de todo tipo en estas está a la orden del día, lo cual en muchos casos puede suponer daños irreparables y no esperados por el artista. Aunque lo más común es que estas se presenten en zonas cercanas a los bordes donde las obras se pueden manipular de forma más fácil y segura, a veces las huellas aparecen en otras zonas que difícilmente habrían ayudado en la manipulación o traslado, y con ello, innecesarias [Figura 7]. Es de conocimiento generalizado que la alteración producida por los aceites (ácidos grasos) presentes en las manos en contacto con cualquier superficie puede ser irreversible incluso si su tratamiento se acomete de forma inmediata. Del mismo modo, será dañina la manipulación con guantes que no están limpios (o que tienden a dejar algún residuo) o que han last four years of experience working in the private sector are described below. These are divided into alterations that occurred during handling and transfer, exhibition and mounting, storage, and previous treatments.

\section{- Handling and transport}

Although one of the basic principles of any art specialist or connoisseur is that works should be handled using gloves (cotton, latex, nitrile), avoiding direct contact of the hands with the surface, handprints and fingerprints of all kinds are commonly found in artwork's surfaces. This can, in many cases, cause irreparable damage not expected by the artist. The most commonly found are in areas close to the edges — where the works can be handled more easily and safely - but sometimes fingerprints appear in other areas that would hardly have helped in the handling or removal, and therefore due to unnecessary handling [Figure 7]. It is common knowledge that the alteration caused by oils (fatty acids) present on hands in contact with any surface can be irreversible - even if treated immediately. Similarly, handling with gloves that are not clean (or that tend to leave some residue)
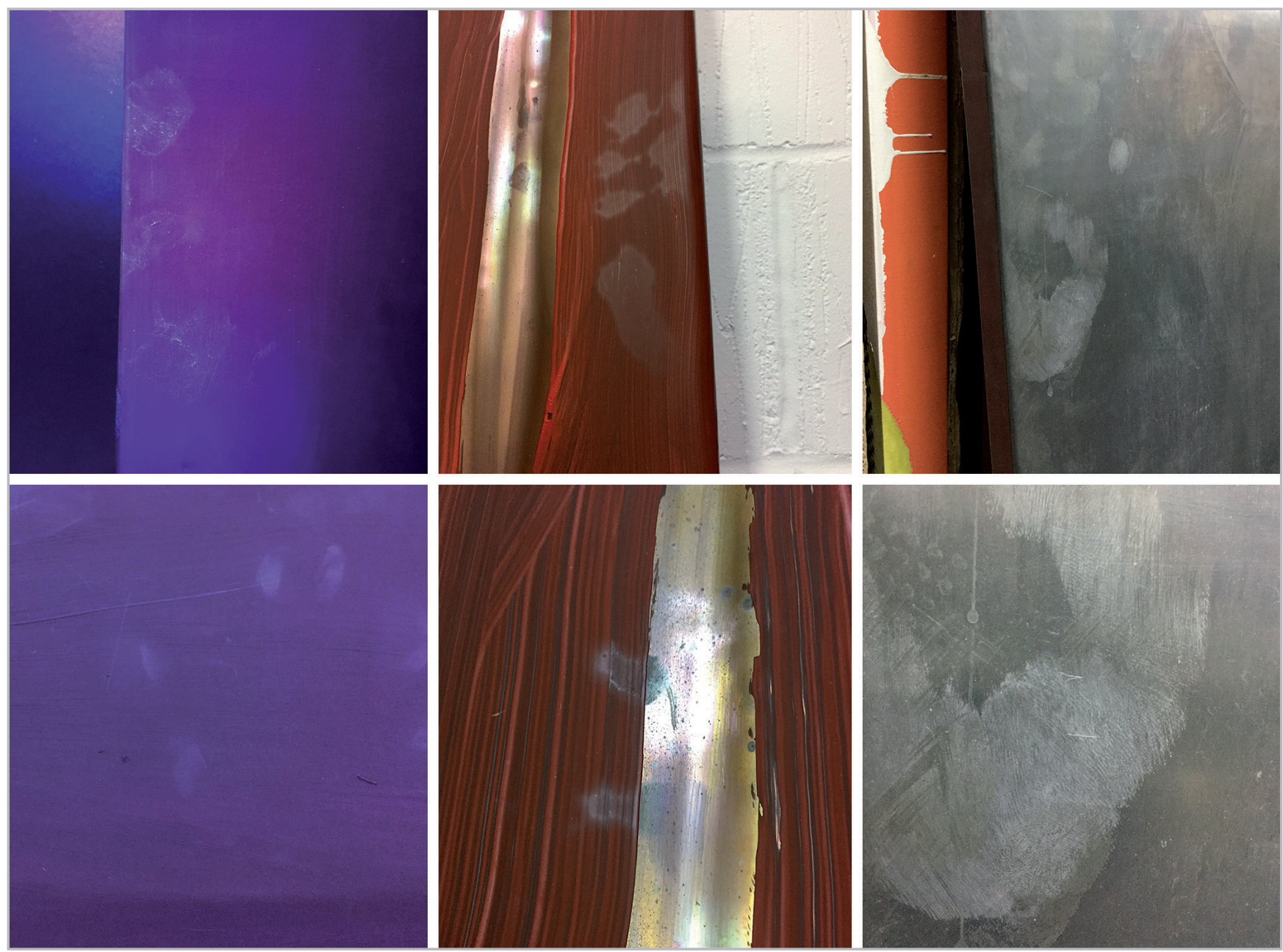

Figura/Figure 7-Huellas por manipulación incorrecta en diferentes superficies. / Traces of mishandling: fingerprints. 
sido empleados con anterioridad, así como puede ser incluso el contacto con guantes limpios sobre superficies frágiles, o que presentan alteraciones como pulverulencias, craqueladuras o escamas, ya que el contacto con cualquier elemento podrá dar pie a la pérdida de materia. Esto supone siempre un problema, pero sobre todo es un desafío cuando estas huellas aparecen en superficies especialmente delicadas, como superficies mates, en colores planos, en soportes metálicos, vírgenes o pulidos, anversos y reversos de pinturas, estructuras de cristal, etc. En casos de superficies frágiles o susceptibles de sufrir cambios por contacto, las acciones de conservación pueden ser muy limitadas debido a que la aplicación de cualquier material de limpieza (húmedo o seco) también podrá producir un cambio estético en la superficie. Por ello se debe tomar conciencia de que la manipulación y el contacto de las obras con superficies sensibles debería ser mínimo o evitarse a toda costa.

En cuestiones de traslado, las problemáticas más comunes se vinculan a movimientos innecesarios y vibraciones, que conllevan a la pérdida de cohesión de los estratos que componen la obra. Pero también se pueden presentar otros daños, como los producidos por golpes, por colocación de obras de forma indebida, por el uso de sistemas de protección obsoletos o no adaptados a las necesidades de las obras, o incluso, y de manera muy frecuente, en obras transportadas en cajas de embalaje no adaptadas o sin materiales amortiguadores. Lo recomendable sería que cualquier obra de arte contemporáneo fuera transportada en cajas rígidas adaptadas a las necesidades de las mismas, al recorrido que van a realizar y al tipo de vehículo de transporte (aéreo, terrestre o marítimo), en cada caso [Figura 8]. Por tanto, las obras deberán ser estabilizadas empleando materiales de protección flexibles pero resistentes en su interior, que eviten movimientos y golpes, que bloqueen todo tipo de vibraciones siempre que sea posible y eviten el contacto con otras obras o superficies durante su traslado y, también, durante su almacenaje. or that have been used before, or even the contact with clean gloves on fragile surfaces (e.g. powdering, cracking or flaking) will be harmful, as the touch of any element can lead to the loss of original material. This is always a problem, but it is especially a challenge when these prints appear on particularly delicate surfaces, such as matt surfaces, on flat colours, on virgin or polished metal supports, on the front and back of paintings, on glass structures, etc. In cases of fragile surfaces or surfaces susceptible to changes, remedial conservation actions may be very limited because the application of any cleaning material (wet or dry) may also produce an aesthetic change on the surface. It is therefore important to be aware that handling and contact of the works with sensitive surfaces should be kept to a minimum or avoided at all costs.

In terms of transport, the most common issues are linked to unnecessary movements and vibrations, which lead to the loss of cohesion of the layers of materials. But other damages can also occur, such as those caused by blows, improper placement of works, the use of obsolete protection systems or those not adapted to the needs of the works, or even, and very frequently, works transported in unsuitable packing boxes or without shock-absorbing materials. It would be advisable for all works of contemporary art to be transported in rigid boxes adapted to the needs of the works, to the route they are going to take and to the type of transport vehicle (air, land or sea), in each case [Figure 8]. The works should be stabilised using flexible but resistant protective materials inside, which prevent movement and shocks, block all types of vibrations whenever possible and prevent contact with other works or surfaces during transport and also during storage.
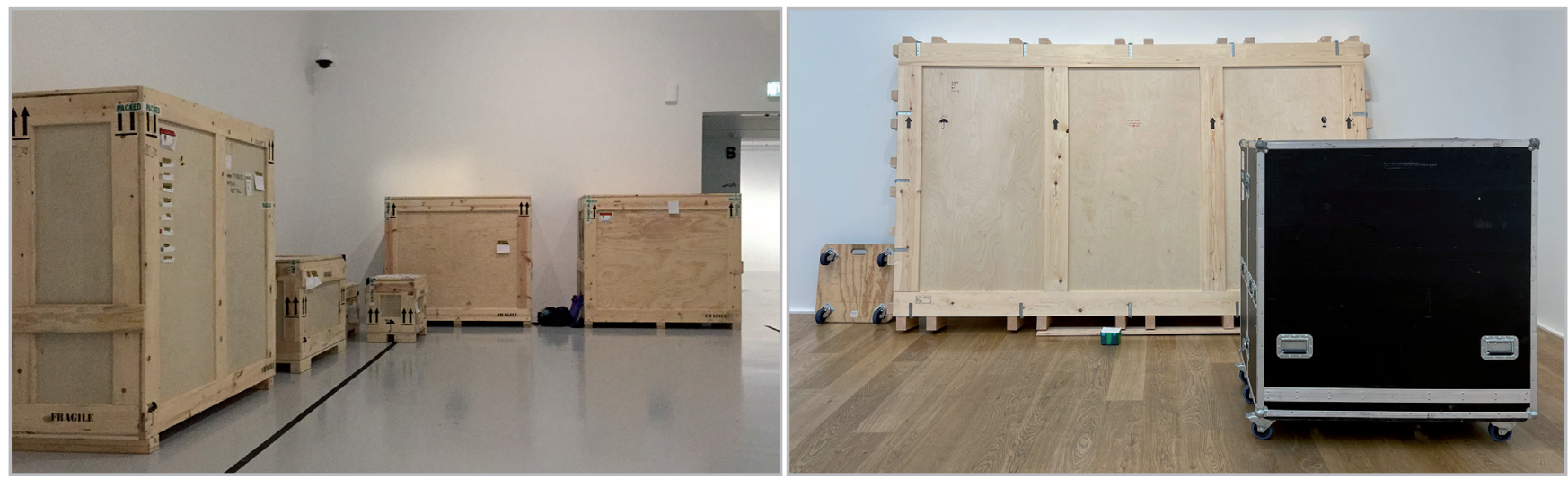

Figura/Figure 8- Diferentes formatos de cajas para transporte de obras de arte. / Different formats of crates for artworks' transport.

\section{- Almacenaje y tratamientos anteriores}

El almacenaje de obras de forma incorrecta es demasiado común en el ámbito privado. El entorno será el principal causante de los daños a los que la obra se enfrente, pero también las medidas tomadas por los responsables con

\section{- Storage and pre-treatment}

Incorrect storage of artworks is all too common in the private sector. The environment will be the main cause of the damage that the work faces, but also the measures taken by those responsible for the piece. Moreover, and 
respecto a la obra. Por un lado, respecto al entorno, se presentan riesgos como la utilización de espacios sucios o donde no hay una limpieza regular, o el almacenaje en zonas con exceso de humedad, susceptibles cambios oscilantes de temperatura o incluso propensas a catástrofes (inundaciones e incendios). Todos ellos causan innumerables daños, desde la alteración de la superficie (sea por los depósitos en esta, como cambios físico-químicos de los materiales), la presencia de manchas a diferentes niveles (moho, blanqueamientos, suciedad), a la completa degradación de la obra. Por otro lado, los riesgos incrementan en las obras cuando estas carecen de protección, al igual que cuando se colocan sobre superficies irregulares, se almacenan de manera incorrecta y sin orden (obras apiladas sin protección entre ellas) o incluso, se abandonan por dejar de tener un uso o valor directamente reconocido. Como se ha expuesto en el punto anterior, el almacenaje de las obras en cajas rígidas puede ser una buena manera de evitar daños directos sobre estas al mismo tiempo que evitan depósitos ambientales sobre las superficies. Otras opciones son los espacios acolchados, con separaciones entre obras y sin elementos móviles que puedan caer sobre las mismas. En todo caso, es imprescindible conservarlas en un espacio acondicionado en el que las fluctuaciones ambientales sean lo más limitadas posibles.

En cuestiones de protección, el uso inadecuado de materiales de embalaje es, en muchos casos, un problema al que se enfrentan los conservadores. Encontrar cintas de precinto altamente adhesivas directamente dispuestas sobre la obra es algo que ocurre más comúnmente de lo que se pudiera esperar. También son frecuentes los casos donde, aunque las cintas adhesivas no se presentan en contacto con la obra, estas crean reacciones indeseadas, incluso fatales sobre la misma, sea por los propios adhesivos o por el exceso de presión sobre el embalaje y la obra. Otro problema es el embalaje a largo plazo, ya que muchas cintas adhesivas no solo no están testadas para su empleo en obras de arte, sino que se degradan tras un corto periodo de tiempo: dejan de tener función adhesiva, se vuelven quebradizas, el adhesivo se vuelve pulverulento, manchan el soporte sobre el que están colocadas, etc. Tales alteraciones presentes en las cintas producen que las mismas dejen de ofrecer resistencia y con ello, fallen en su función envolvente de los materiales de protección, por lo que las obras quedan desprotegidas o afectadas por los residuos o materiales residuales de la misma cinta.

Respecto a los materiales de embalaje y barreras de protección, existen embalajes altamente acídicos que pueden causar daños estéticos (por ejemplo, manchas). Pero estos no son el único problema, ya que algunos materiales previamente testados para su uso en la preservación de obras en ocasiones también pueden generar problemas. Por ejemplo, el uso de capas de materiales de embalaje tipo Tyvek ${ }^{\circledast}$, Glassine ${ }^{\circledR}$ o tissue directamente sobre estratos frescos o todavía en proceso de secado [Figura 9]. La mayoría de estas tipologías de estratos protectores permiten la transpiración mientras protegen las obras de depósitos externos, pero al aplicarse en estratos todavía húmedos puede ser fatal para la obra ya que dependiendo de la composición material de la misma, el tipo de embalaje es with regard to the environment, there are risks such as the use of dirty spaces or spaces where there is no regular cleaning, or storage in areas with excessive humidity, susceptible to oscillating temperature changes or even prone to catastrophes (floods and fires). All of these cause incommensurable damage, from alteration of the surface (either by deposits on it, or physical-chemical changes of the materials), the presence of stains at different levels (mould, bleaching, dirt), to the complete degradation of the work. The risks increase when the artworks lack protection, when they are placed on irregular surfaces, when they are stored incorrectly and without order (e.g. works stacked without protection between them) or even when they are abandoned because they no longer have a directly recognised use or value. As discussed in the previous point, storing works in rigid boxes can be a good way to avoid direct damage to the artworks while avoiding environmental deposits on the surfaces. Other options are cushioned spaces, with separations between artworks and without mobile elements that could fall on them. In any case, it is essential to keep them in a conditioned space where variations in environmental fluctuations are as limited as possible.

In terms of protection, the inappropriate use of packaging materials is, in many cases, a problem faced by conservators. Finding highly adhesive sealing tapes directly on the artwork is a more common occurrence than might be expected. There are also frequent cases where, although the adhesive tapes do not come into contact with the artwork, they create unwanted, even fatal reactions on it, either from the adhesives themselves or from excessive pressure on the packaging and the artwork. Another problem is longterm packaging, as many adhesive tapes are not only not tested for use on artistic protection purposes, but also degrade after a short period of time: they no longer have an adhesive function, they become brittle, the adhesive becomes powdery, they stain the support on which they are placed, etc. Such alterations cause the tapes to cease to offer resistance and thus fail in their function of enveloping the protective materials, so that the artworks become unprotected or affected by the residues or residual materials of the tape itself.

With regard to packaging materials and protective barriers, there are highly acidic packaging materials that can cause aesthetic damage (e.g. stains). However, these are not the only problem, as some materials previously tested for use in the preservation of art can sometimes also cause problems. For example, the use of layers of packaging materials such as Tyvek ${ }^{\circledast}$, Glassine ${ }^{\circledR}$ or tissue directly on fresh or still drying layers. Most of these types of protective barriers allow for breathability while protecting the works from external accretions, but when applied to still wet layers it can be fatal to the artwork [Figure 9]. This is because depending on the material composition of the work, the type of 
susceptible de ser adherido a la materia fresca siendo imposible su separación segura. Por si no fuera suficiente, el Tyvek ${ }^{\circledR}$, al igual que otros materiales sin capas siliconadas, puede llegar a dejar pequeñas fibras sobre las capas pictóricas húmedas o de material fresco. En estos casos, lo prudente sería evitar la protección de la superficie hasta su completo secado y, si fuera necesario posponer su almacenaje o traslado, el cual debería realizarse evitando el contacto de la superficie todavía fresca con cualquier otro material, o si no fuera posible, usar en todo caso de ser necesario el traslado, evaluar las necesidades directas de la obra y fijarla de forma segura en cajas con contramarco (marco de viaje) o adaptadas a la pieza, en la que la superficie fresca no toque ninguno otro elemento. Del mismo modo, ante la aparición de problemas potenciales vinculados a la cubrición de las superficies en obras con materiales de secado lento, una de las propuestas que se ofrecen para evitar daños a gran escala es el uso de materiales de protección testados y aprobados en el campo de la conservación y que no ofrezcan resistencia durante su eliminación como son los Melinex ${ }^{\circledR}$ siliconados o los Nylon Dartek $^{\circledast}$. packaging is likely to adhere to the fresh material making it impossible to separate it safely. As if that was not enough, Tyvek $^{\circledR}$, like other materials without silicone release layers, can leave small fibres on wet paint layers or on fresh material. In these cases, it would be prudent to avoid protecting the surface until it is completely dry and, if necessary, to postpone storage or removal. In any case, this should be done avoiding touching the still fresh surface with any other material, or if this is not possible, to assess the direct needs of the work and to secure it safely in travel boxes (T-frame) or adapted to the piece, in which the fresh surface does not touch any other element. Similarly, in the face of potential problems linked to the covering of surfaces of artworks with slow-drying or sensitive materials, one of the proposals offered to avoid large-scale damages is the use of protection materials tested and approved in the field of conservation and which do not offer resistance during removal, such as siliconed Melinex ${ }^{\circledR}$ or Nylon Dartek ${ }^{\circledast}$.
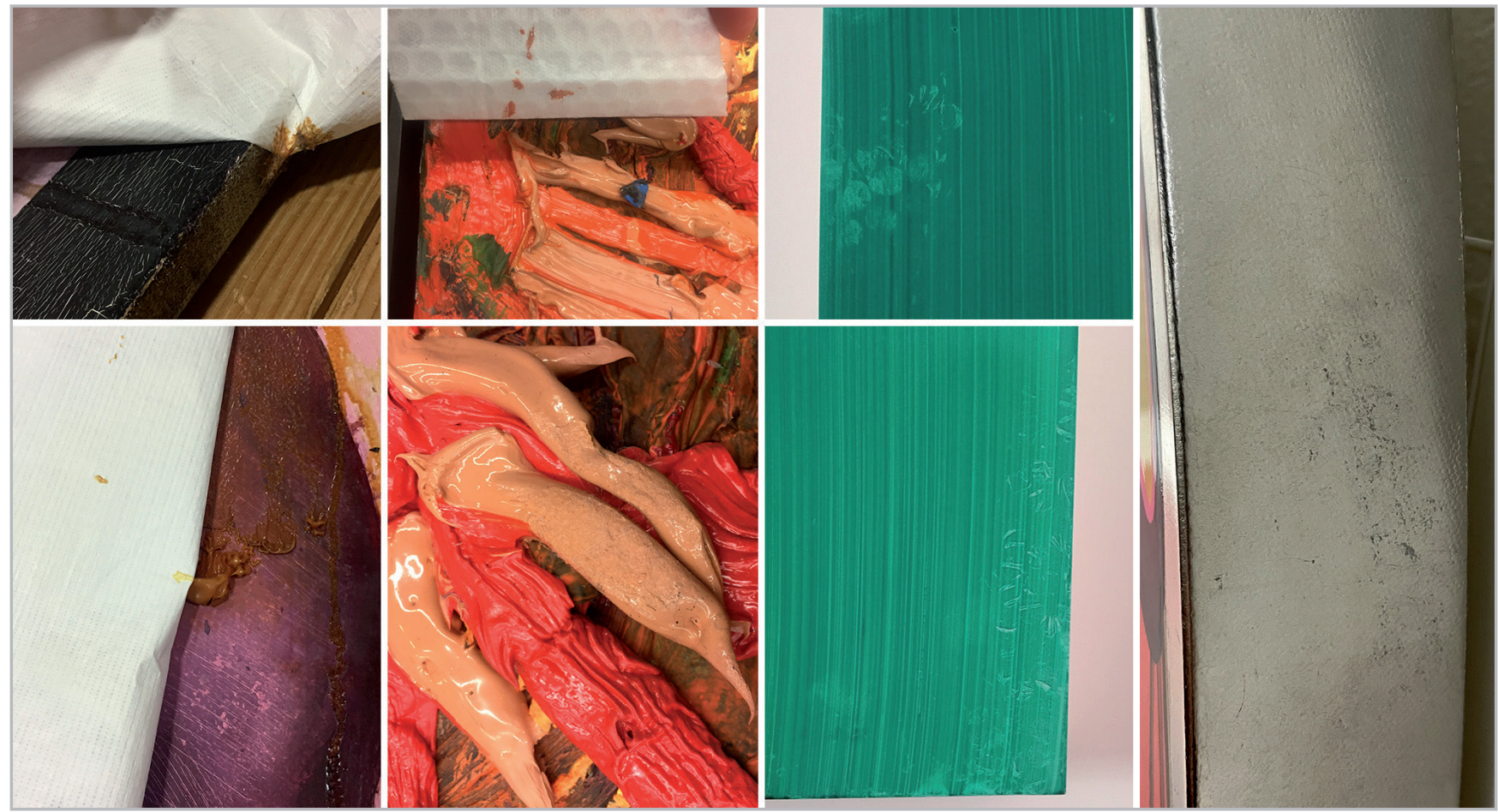

Figura/Figure 9- . Problemas de embalaje comunes en superficies pictóricas. / Common packaging problems on painted surfaces.

\section{- Exposición y montaje}

Respecto a los desafíos y procedimientos de conservación comunes en exposición y montaje, los preparativos de los espacios y de las obras son un tema que debe ser tratado necesariamente, debido a la cantidad de problemáticas que estos pueden producir. En el caso de piezas u obras de grandes dimensiones que requieren montaje o deben instalarse en espacios con acceso reducido, el trabajo del conservador es fundamental y vital. Cuando se trata de esculturas e instalaciones, la obra va normalmente acompañada de instrucciones concretas de cómo proceder, pero en algunos casos, las piezas pueden ser

\section{-Exhibition and installation}

With regard to the common conservation challenges and procedures in exhibition and mounting, the preparation of spaces and works is a subject that must necessarily be dealt with, due to the number of problems that can arise. In the case of large pieces or works that require mounting or must be installed in spaces with reduced access, the work of the conservator is fundamental and vital. In the case of sculptures and installations, the artwork is normally accompanied by specific instructions on how to proceed, but in some cases, the pieces may be transported already assembled and on 
trasladadas ya montadas y al llegar al lugar de instalación, se requiere de su desmontaje, proceso que puede no haber ocurrido anteriormente y por lo tanto, en este caso, la instalación requerirá de una investigación previa, realizando el contacto con el artista y/o el fabricante, los cuales podrán ofrecer las instrucciones necesarias para asegurar que el proceso de desmontaje y montaje seguido es correcto. En estas situaciones, es recomendable que todas las acciones llevadas a cabo sean supervisadas por un conservador, el cual asegurará que las instrucciones de desmontaje y montaje facilitadas por la persona o equipo que produjo la obra sean aplicadas correctamente. El conservador, además, evaluará los riesgos y posibles interferencias del traslado en el entorno escogido por el cliente.

Igualmente, es necesario destacar que las tareas de desmontaje de cualquier tipo de obra serán situaciones de riesgo añadidas a la misma, por ejemplo, en el caso de lienzos de gran formato, es corriente aplicar la práctica del destensado y desclavado, procediendo al transporte de la obra enrollada en un tubo, para que sea luego retensada en su bastidor en la nueva localización. Este proceso puede ser especialmente crítico para la pintura si no se tienen en cuenta las características de la misma, como: la superficie (por ejemplo, cuando presentan empastes o superposición de estratos pictóricos), el tamaño de la obra, el peso y su tensión, así como su estado de conservación. Es posible que la evaluación previa identifique zonas donde deban ser aplicadas medidas de conservación previamente a enrollar y trasladar la obra, así como cierta concienciación sobre qué mecanismo de enrollado y qué materiales auxiliares serán necesarios en el proceso (Gili 2013). Además, estas actividades serán no solo supervisadas por un equipo de conservadores, sino también ejecutadas con ayuda de técnicos especialistas en este tipo de acciones.

Los encargados de la exhibición de obras de arte durante los preparativos para su exposición o venta, ya sea en una galería, una feria o una casa de subasta, suelen contar con conservadores para asegurar la correcta preparación de las obras y que su estado de conservación sea idóneo para su inclusión en el catálogo y su presentación al público. Estas tareas incluyen no solo atender a las situaciones previamente mencionadas sino también a aplicar todas las acciones que sean necesarias para presentar la obra en su mejor estado, tareas que van desde la realización de informes de conservación que complementan la información recogida por los registradores in situ, identificando alteraciones y posibles causas, a tareas específicas, como tratamientos estructurales y estéticos debido a alteraciones específicas, pasando por la limpieza superficial de las obras.

De hecho, la limpieza superficial de obras es uno de los tratamientos de conservación más frecuentes que forman parte de los preparativos de estos eventos, aunque a veces también se pueden realizar tratamientos específicos. Las obras, sobre todo las que se preparan para una reventa, pueden presentar desde daños puntuales, pérdida de estabilidad generalizada o localizada, así como tratamientos inadecuados realizados en el pasado. Indudablemente, cada vez existe mayor concienciación sobre la necesidad de contar con los conservadores de arte arrival at the exhibition site, dismantling might be required to access the space, a process which might not have occurred previously. In cases like this, the installation will require prior research, making contact with the artist and/or the manufacturer, who can provide the necessary instructions to ensure that the dismantling and assembly process followed are correct. In these situations, it is advisable that all actions carried out are supervised by a conservator, who will ensure that the dismantling and assembly instructions provided by the person or team that produced the artwork are correctly applied. The conservator will also assess the risks and possible interferences of the removal in the environment chosen by the client.

Similarly, it should also be noted that dismantling any type of artwork will be an additional risk situation. For example, in the case of large canvases, it is common to apply the practice of untensioning and unpinning (unstretching), transporting the work rolled up in a tube, so that it can then be re-tensioned (re-stretching) on its stretcher or strainer in its new location. This process can be particularly critical for the painting if tits characteristics are not taken into account, such as: the surface (for example, when there are impasto or overlapping pictorial layers), the size of the work, its weight and tension, as well as its conservation condition. The pre-assessment may identify areas where conservation measures should be applied prior to rolling and moving the work, as well as some awareness of what rolling mechanism and what auxiliary materials will be needed in the process (Gili 2013). Moreover, these activities will not only be supervised by a team of conservators, but also carried out with the help of technicians specialised in this type of action.

Those in charge of the exhibition of works of art during the preparations for their exhibition or sale, whether in a gallery, at a fair or at an auction house, usually have conservators to ensure the correct preparation of the works for their inclusion in the catalogue and their presentation to the public. These tasks include not only attending to the aforementioned situations but also applying all the necessary actions to present the work in its best conservation condition, ranging from generally organising the preparation of condition reports that complement the information collected by the registrars in situ, identifying alterations and possible causes, to specific tasks, such as structural and aesthetic treatments due to specific alterations, as well as the superficial cleaning of the artworks.

In fact, the superficial cleaning of artworks is one of the most frequent conservation treatments that forms part of the preparations for these events, although sometimes specific treatments can also be carried out. Artworks, especially those being prepared for resale, may present punctual damage, generalised or localised loss of stability, as well as inadequate treatments carried out in the past. Undoubtedly, there is a growing awareness of the need to rely on contemporary art conservators in 
contemporáneo en estos casos, así como la concienciación de la necesidad de dichos tratamientos de conservación de arte contemporáneo, pero se podría afirmar que no es la norma, ya que la novedad de los procedimientos (y las metodologías y teorías a seguir) en el arte contemporáneo pueden no haber llegado a ciertos profesionales del sector. Puede ocurrir que una obra presente un tratamiento previo que resulta demasiado aparente, y que se considere invasivo, inapropiado o que sea completamente irreversible. Esto es algo bastante común en el retoque de superficies pintadas y en aquellos soportes modernos que han sido impresos industrialmente [Figura 10]. En estos casos la tarea del conservador será evaluar si la eliminación del tratamiento previo es posible sin dañar la obra, y si su permanencia puede afectar negativamente a la obra a largo plazo. these cases, as well as an awareness of the need for such contemporary art conservation treatments. However, it could be argued that this is not the norm, as the novelty of the procedures (and new methodologies and theories to be followed) in contemporary art may not have reached certain professionals in the sector. It can happen that an artwork presents a pre-treatment that is too apparent, and is considered invasive, inappropriate or completely irreversible. This is quite common in the retouching of painted surfaces and in modern supports that have been industrially printed [Figure 10]. In these cases, the conservator's duty will be to assess whether the removal of the pre-treatment is possible without damaging the work, and whether its permanence may adversely affect the work in the long term.
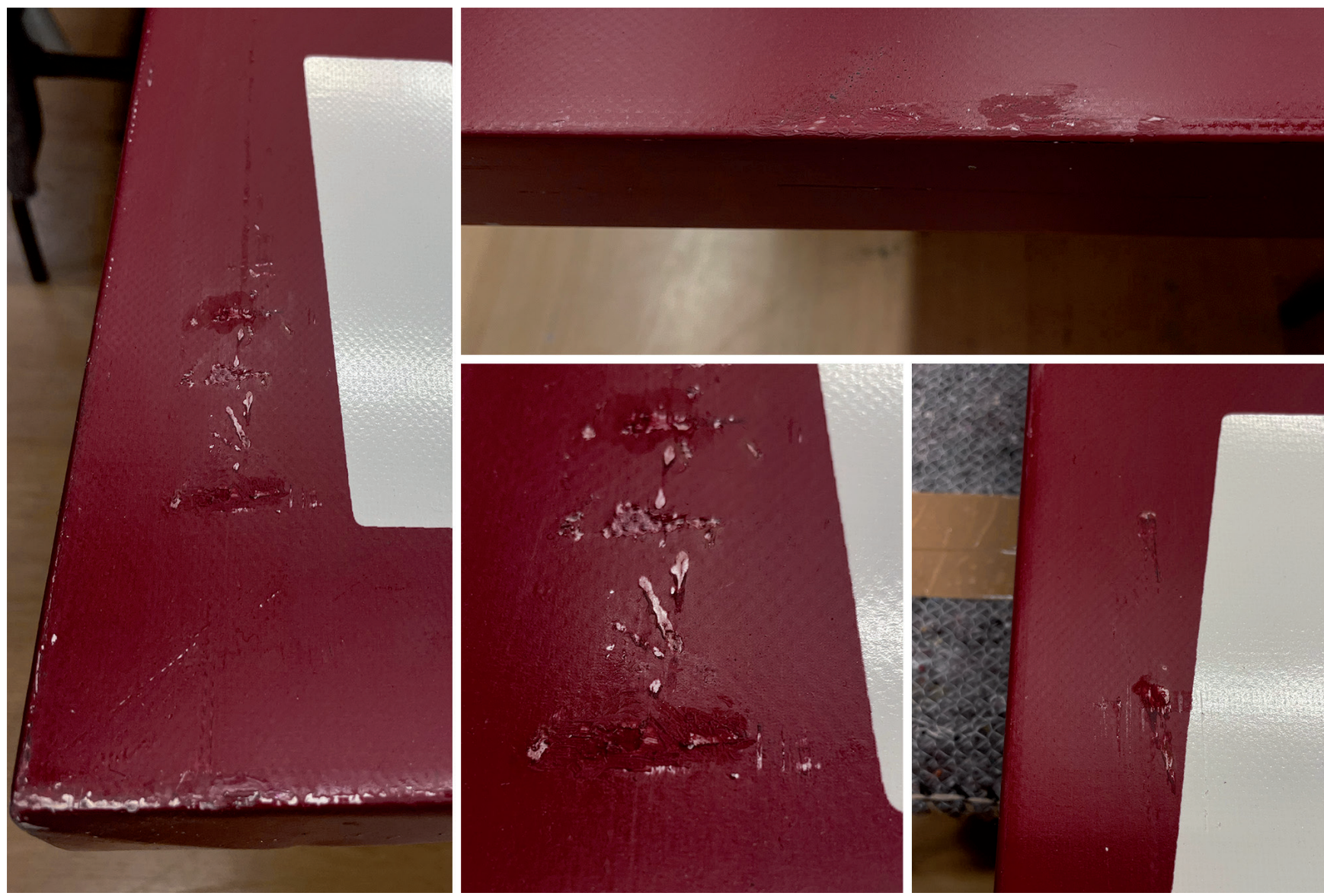

Figura/Figure 10- Retoque inadecuado en soporte de vinilo impreso. / Inadequate retouching on printed vinyl support.

Otro de los desafíos a los que se enfrentan los conservadores en este ámbito, son los relacionados con los daños estéticos, las correcciones de errores de producción o producidos mientras obras ya terminadas aun se presentaban en el estudio del artista. Uno de los aspectos más relevantes en estos casos es establecer el tipo de alteración identificada y proceder de una manera ética. Pueden aparecer fallos de manufactura que pueden ser pequeñas ralladuras en superficie de objetos, exceso de pintura (gotas) en cuadros o restos de fibras de pincel en superficies diversas, entre otros. En estos casos, si estos no han sido localizados y corregidos por el artista se deben considerar parte de la obra y no deben ser modificados,
Another challenge faced by conservators in this field is related to aesthetic damage, the correction of production errors or errors that occurred while finished works were still in the artist's studio. One of the most relevant aspects in these cases is to establish the type of alteration identified and to proceed in an ethical manner. Manufacturing faults may appear, such as small scratches on the surface of objects, excess paint (drops) on paintings, or traces of brush fibres on various surfaces, among others. In these cases, if they have not been located and corrected by the artist, they should be considered part of the work and should not be modified, as these faults can often be part 
ya que muchas veces estos fallos pueden formar parte de la intención del artista. Con respecto a errores que supongan un daño estético relevante en la obra o haya incertidumbre sobre cuándo se produjo la alteración (por ejemplo, salpicaduras con un color no empleado en una obra pictórica), será siempre recomendable contactar con el artista o su legado para determinar la mejor opción de cómo proceder. Este paso puede incluirse en la toma de decisiones tras contactar con el cliente [Figura 6], ya que favorecerá en la propuesta de intervención (o decisión de no continuar con el proceso por cuestiones éticas).

\section{Conclusiones. Hacia una propuesta de plan de preven- ción adaptada al sector privado}

El sector más comercial del arte es actualmente parte intrínseco del mismo, como lo es el coleccionismo a diferentes niveles y en diferentes entornos. A pesar de las limitaciones de acceso que la adquisición de obras de arte con alto valor (artístico, histórico y también económico) presenta, el disfrute de las mismas no siempre queda permanentemente limitado a unos pocos en el sector privado, ya que el seguimiento de galerías y eventos relacionados con la exposición y compra-venta de estas obras ayuda en la apreciación de obras que generalmente son menos accesibles.

No obstante, la adquisición de obras de arte de cualquier tipo y en cualquier nivel de coleccionismo, implica una gran responsabilidad. Por ello, propietarios privados, galeristas, especialistas, gestores, registradores, técnicos de exposiciones y toda persona que tenga acceso a estas obras a largo, medio o corto plazo deberán siempre atender a unos parámetros concretos para la mejor conservación de las mismas, y ante cualquier duda o incertidumbre respecto a la manipulación, traslado, almacenaje o exposición de la pieza, contactar con un especialista en conservación que le ayude a identificar posibles riesgos y daños que puedan ocurrir en tales situaciones.

A partir de la información presentada en este artículo y como conclusión al mismo, a continuación, se presentan una serie de acciones accesibles a todo coleccionista, propietario, galerista o amante del arte para el cuidado de sus obras de arte contemporáneo.

Las obras de arte en un espacio habitado regularmente (a cualquier nivel) tendrán, por lo general, unas condiciones de temperatura y humedad constantes, adaptadas a las personas que frecuentan tal espacio, lo cual por lo general puede ser idóneo para las obras. Sin embargo, si la obra se encuentra en un foco directo de calor o frío, su degradación puede aumentar notablemente. Se recomienda por tanto mantener las obras lejos de aparatos de aire acondicionado, ventiladores, radiadores, estufas, electrodomésticos que irradien calor, o cualquier fuente de aire o humedad, así como de luz directa del sol o focos incandescentes. Con relación a lo anterior, otras acciones más avanzadas serán proteger las obras de la luz directa empleando barreras con filtros UV. Estas pueden aplicarse a ventanas o en vitrinas y obras enmarcadas. Proteger las obras con barreras físicas (con o sin protección UV), tiene dos beneficios directos para las obras: protegerlas de los rayos of the artist's intention. With respect to errors that involve significant aesthetic damage to the work or uncertainty as to when the alteration occurred (e.g. splashes of a colour not used in a pictorial piece), it is always advisable to contact the artist or the artist's estate to determine the best course of action. This step can be included in the decision-making process after contacting the client [Figure 6], as it will help in the proposed intervention (or in making the decision not to continue with the process due to ethical issues).

\section{Conclusions. Towards a proposal for a preventive con- servation plan adapted to the private sector}

The art market has always been an intrinsic part of the Art World, as is collecting at different levels and in different environments. Despite the limitations of access that the private acquisition of artworks with high value (artistic, historical and also economic) presents, the enjoyment of these pieces is not always permanently limited to a few in the private sector, as the following by the public of galleries and events related to the exhibition and sale of privatelyowned works allows for the appreciation of pieces that are generally less accessible.

Nevertheless, the acquisition of artworks of any kind and at any level of collecting involves a great deal of responsibility. Therefore, private collectors, gallery owners, art specialists, managers, registrars, exhibition technicians and anyone who has access to artworks in the long, medium or short terms should always pay attention to specific parameters for the best conservation of these, and in case of any doubt or uncertainty regarding the handling, move, storage or exhibition of a piece, should always contact a conservation specialist to help identify possible risks and damage that may occur in such situations.

Based on the information presented in this article and as a conclusion to it, the following is a series of actions accessible to any collector, gallery owner or art lover for the care of their contemporary artworks.

Works of art in a regularly inhabited space (at any level) will generally have constant temperature and humidity conditions, adapted to the people who frequent such a space, which can generally be ideal for the pieces. However, if an artwork is located in a direct source of heat or cold, its degradation may increase significantly. It is therefore recommended to keep artworks away from air conditioners, fans, radiators, cookers, heat radiating appliances, or any source of air or moisture, as well as direct sunlight or incandescent bulbs. In relation to the above, other more advanced actions will be to protect the pieces from direct light by using UV filter barriers. These can be applied to windows or on display cases and framed works. Protecting the works with physical barriers (with or without UV protection) has two direct benefits for the works: protecting them from direct UV rays and avoiding the accumulation of 
UV y evitar la acumulación de suciedad en la superficie de las mismas, esto evitará problemas futuros.

Respecto a la manipulación y traslado de las obras, existen manuales que exponen métodos de trabajo evitando producir daños sobre las obras a toda costa ${ }^{[6]}$. El uso de guantes limpios, y sobre todo, evitar el contacto con las superficies de las obras, utilizando los soportes secundarios como bastidores, marcos, plintos, etc., para moverlas son aspectos principales, así como evaluar e identificar las zonas de menor riesgo o nulo para el transporte de las mismas previo a cualquier acción de manipulación. Esto se complementa con el uso de métodos correctos de embalaje y protección durante el transporte y almacenaje, como cajas rígidas adaptadas a la forma y necesidad de la obra. Seguir los manuales o las instrucciones de montaje también pueden ayudar en este aspecto, ya que tendrán consideraciones específicas sobre la manipulación, almacenaje y mantenimiento de las obras.

Como conclusión se podría decir que la labor del conservador de arte contemporáneo en el sector privado se centra en el mejor mantenimiento de las obras y en trabajar de una manera adaptada con clientes y otros profesionales estableciendo un diálogo accesible para todos, exponiendo las necesidades de la obra y sugiriendo cambios adaptados en cada caso, con el objetivo de evitar daños así como evaluar posibles riesgos a corto, medio y largo plazo.

\section{Notas}

[1] En 1922, durante las excavaciones de la antigua ciudad de Ur en Babilonia, Leonard Woolley descubrió una colección de objetos catalogados y correspondientes al museo de Ennigaldi, uno de los primeros museos conocidos, datado del siglo $\mathrm{V}$ a.E.C. (Woolley 1962:17).

[2] En el texto se emplea conservación para determinar todas las acciones de preservación, conservación y restauración aplicables a obras de arte y objetos del patrimonio histórico-artístico. Basado en Terminología para definir la conservación del patrimonio cultural tangible (ICOM-CC 2009).

[3] Si el daño es directo y no ha sido frenado, este será el momento en que el conservador aplique una medida de emergencia y detenga el mismo.

[4] La cuestión de la diversidad y variedad de posibilidades en los procesos de toma de decisiones en diferentes sectores fue demostrada recientemente por Joy Bloser, Julia Betancor, Miroslaw Wachowiak y Marieke Opeña en el webinar Spring CAN! Conversation: Contextualizing the decision-making model in contemporary art conservation (AIC 2021).

[5] Basadas en asociaciones internacionales por la conservación del patrimonio como ECCO o ICOM.

[6] Algunos ejemplos de consulta: Art in Transit: Handbook for dirt on the surface of the works, which will prevent future problems.

Regarding the handling and moving of the works, there are manuals that outline working methods to avoid damaging the works at all costs ${ }^{[6]}$. The use of clean gloves, and above all, avoiding contact with the surfaces of artworks - using secondary supports such as frames, plinths, etc. - when moving them, are the main aspects, as well as evaluating and identifying the areas of least risk or no risk for the transport of the works prior to any handling action. This is complemented by the use of correct packaging and protection methods during transport and storage, such as rigid crates adapted to the shape and needs of the work. Following manuals or assembly instructions can also help in this respect, as they will have specific considerations on handling, storage and maintenance of the works.

In conclusion, it could be said that the duties of the contemporary art conservator in the private sector focus on the best care of artworks, always working in an openminded way with clients and other professionals. This is produced by establishing a dialogue accessible to all, exposing the needs of the artworks and suggesting changes adapted in each case, with the aim of avoiding damage as well as assessing possible risks in the short, medium and long terms.

\section{Notes}

[1] In 1922, during excavations at the ancient city of Ur in Babylonia, Leonard Woolley discovered a collection of catalogued objects from the museum of Ennigaldi, one of the earliest known museums, dating from the 5th century BC. (Woolley 1962:17).

[2] Conservation is used in the text to refer to all actions of preservation, conservation and restoration applicable to works of art and objects of heritage. Based on Terminology to Characterize the Conservation of Tangible Cultural Heritage (ICOMCC 2009).

[3] If the damage is direct and has not been stopped, this is the moment for the conservator to apply an emergency measure and stop the damage.

[4] The issue of the diversity and variety of possibilities in decisionmaking processes in different sectors was recently demonstrated by Joy Bloser, Julia Betancor, Miroslaw Wachowiak, and Marieke Opeña in the webinar Spring CAN! Conversation: Contextualizing the decision-making model in contemporary art conservation (AIC 2021).

[5] Based on international heritage conservation associations such as ECCO or ICOM. 
Packing and Transporting Paintings (Richard et al. 1997) y The Care and Handling of Art Objects: Practices in the Metropolitan Museum of Art (Shelley 1987). and Transporting Paintings (Richard et al. 1997) and The Care and Handling of Art Objects: Practices in the Metropolitan Museum of Art (Shelley 1987).

\section{Referencias / references}

AIC (2021). Spring CAN! Conversation: Contextualizing the decision-making model in contemporary art conservation, Talks by Bloser, Joy; Betancor, Julia; Wachowiak, Miroslaw; and Opeña, Marieke. Live Webinar, American Institute for Conservation [4 de abril de 2021]

BOLAÑOS, M. (2009). Historia de los museos en España: memoria, cultura, sociedad. Madrid: Trea.

BRODIE, N.(2019). "The 'Art World' of the Auction Houses: The Role of Professional Experts". Arts 8 (2): 56. https://doi.org/10.3390/ arts8020056 [11 de abril de 2021]

DALL'AGLIO, S. (2020). "The great collector and his man in Rome. Leopoldo de' Medici and his letters to Ottavio Falconieri, 1662-75". Journal of the History of Collections, 32 (3): 431-442. https://doi-org.eres.qnl.qa/10.1093/jhc/fhz040

DELBOURGO, J.(2017). Collecting the World: The Life and Curiosity of Hans Sloane. Londres: Penguin.

GARCÍA F; DE LOS SANTOS, M. ET AL.(2018) "Los orígenes, 1819-33". En: Portús Pérez, Javier (coord.) Museo del Prado 1819-2019. Un lugar de memoria. Madrid: Museo Nacional del Prado. 22-47.

GIEBELER, J. ET AL. (2019). The Decision-Making Model for Contemporary Art Conservation and Presentation. Colonia: Cologne Institute of Conservation Sciences / TH Köln.

GILI,P. (2013)."Awareness in rolling, research about its effects and use of polyurethane memory foam", CeROArt. https://doi.org/10.4000/ceroart.3136 ICOM-CC (2009). Terminología para definir la conservación del patrimonio cultural tangible. 15a Conferencia Trienal, New Delhi, $22-26$ de septiembre de 2008.

LINDEMANN, A. (2006). Collecting Contemporary Art. Koln: Taschen.

MCINTOSH, WILLIAM D. Y SCHMEICHEL, BRANDON (2004). “Collectors and Collecting: A Social Psychological Perspective". Leisure Sciences, 26(1): 85-97.

NTOULIA, ELISSAVET (2017). "The birth of the public museum", Wellcome Collection, Stories. https://wellcomecollection.org/articles/ W OkHhEAADUAbHiJ [11 de abril de 2021]

PARDO-TOMÁS, JOSÉ (2018). "La historia natural y el coleccionismo en gabinetes de curiosidades y museos de papel”. María Sybilla Merian y Alida Withoos: mujeres, arte y ciencia en la Edad Moderna. Santander: Editorial Universidad de Cantabria, 59-66. http://hdl.handle. net/10261/172187

RICHARD, MERY T ET AL. (Eds.) (1997) Art in Transit: Handbook for Packing and Transporting Paintings. Washington DC: The National Gallery of Art.

SHELLEY, MARJORIE (1987) The Care and Handling of Art Objects: Practices in the Metropolitan Museum of Art. Nueva York: The Metropolitan Museum of Art.

WOOLLEY, LEONARD (1962). Ur Excavations. the Neo-Babylonian and Persian Periods. Londres: The Trustees of the British Museum. 


\section{Autor/es}

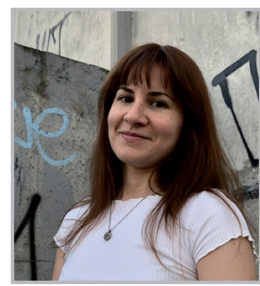

\section{Rita L. Amor García}

rita@cons-graf.com

Cons-Graf. Londres, Reino Unido

www.cons-graf.com

https://orcid.org/0000-0002-8456-3075

Doctora en Ciencia y Restauración del Patrimonio HistóricoArtístico por la Universitat Politècnica de València (UPV). Además, es Licenciada en Bellas Artes (2010) y Posgraduada en Conservación y Restauración de Bienes Culturales (2011) por la UPV. Desde 2010, combina el trabajo de conservador en ambientes multidisciplinares con la investigación sobre materiales contemporáneos, centrándose en la conservación de pintura en aerosol dentro de los movimientos del grafiti y arte urbano, así como el uso en sectores más institucionales y vinculados a la conservación en sectores privados. Entre 2011 y 2014, trabajó como becaria de especialidad en proyectos de investigación vinculados al uso de nuevos materiales y adaptación de procedimientos para pinturas murales arrancadas, dentro del Instituto Universitario de Restauración del Patrimonio. Tras finalizar su tesis doctoral en 2017, comenzó a trabajar como conservadora de superficies pictóricas y objetos no convencionales en Londres en el estudio privado de conservación Plowden and Smith, Ltd. Desde entonces, ha realizado proyectos en diferentes instituciones públicas y privadas a nivel internacional en Europa, Estados Unidos y el Medio Oriente. La Dra Amor García ha realizado colaboraciones con artistas, trabajando en diferentes momentos del proceso creativo, ofreciendo apoyo y soluciones a cuestiones particulares y recomendaciones prácticas para la producción artística. Además ha empleado y adaptado la entrevista a artistas a sectores artísticos alternativos. Gracias a todo ello, ha escrito numerosos artículos de difusión científica y participado en congresos a nivel internacional con su trabajo con materiales contemporáneos, experiencia con artistas y su investigación en la conservación de grafiti y arte urbano.

Artículo enviado el 08/11/2021 Artículo aceptado el 04/12/2021

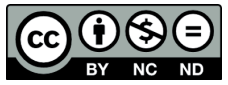

https://doi.org/10.37558/gec.v20i.1077 